\title{
Effect of watering regime and media components on the production of organic tomato transplants
}

\author{
Melissa C. VanTine \\ West Virginia University
}

Follow this and additional works at: https://researchrepository.wvu.edu/etd

\section{Recommended Citation}

VanTine, Melissa C., "Effect of watering regime and media components on the production of organic tomato transplants" (2004). Graduate Theses, Dissertations, and Problem Reports. 2018.

https://researchrepository.wvu.edu/etd/2018

This Thesis is protected by copyright and/or related rights. It has been brought to you by the The Research Repository @ WVU with permission from the rights-holder(s). You are free to use this Thesis in any way that is permitted by the copyright and related rights legislation that applies to your use. For other uses you must obtain permission from the rights-holder(s) directly, unless additional rights are indicated by a Creative Commons license in the record and/ or on the work itself. This Thesis has been accepted for inclusion in WVU Graduate Theses, Dissertations, and Problem Reports collection by an authorized administrator of The Research Repository @ WVU. For more information, please contact researchrepository@mail.wvu.edu. 
Effect of Watering Regime and Media Components on the Production of Organic Tomato Transplants

\author{
Melissa C. VanTine
}

Thesis submitted to the Davis College of Agriculture, Forestry and Consumer Sciences

at West Virginia University

in partial fulfillment of the requirements for the degree of

\author{
Master of Science \\ in \\ Horticulture
}
Sven Verlinden, Ph.D., Major Professor
Louis McDonald, Ph.D
James Kotcon, Ph.D
Department of Plant and Soil Sciences

\author{
Morgantown, West Virginia \\ 2004
}

Keywords: Compost, Organic Production, Tomato, Watering Regime, Transplant Production, Growing Media 


\title{
ABSTRACT \\ Effect of Watering Regime and Media Components on the Production of Organic Tomato Transplants
}

\begin{abstract}
Melissa C. VanTine
In order to find appropriate methods to produce quality organic tomato transplants, tomato (Lycopersicon esculentum cv. WV '63) seedlings were grown in four growing media containing various ratios of composted animal manure and were compared to transplants grown in a conventional peat-lite mix receiving synthetic fertilizers. These five media were watered according to eight watering regimes, including five watering levels and three watering regimes containing compost tea. Composted horse and cow manure can be used in part or instead of peat in organic potting mixes. The ratio of compost used will depend on characteristics of the compost and will also determine the effect of the watering regime on the growth of tomato transplants. In this study, compost tea was not found to have a significant impact the growth of tomato transplants.
\end{abstract}




\section{ACKNOWLEDGEMENTS}

I would like to thank the many people at West Virginia University who have helped me to become a graduate with my Master's in Horticulture. First I would like to thank Dr. Sven Verlinden who believed in my abilities and encouraged me to push for the answers. I would like to thank Dr. James Kotcon and Dr. Louis McDonald who have taught me many aspects regarding science as well as the ability to question the processes around me. A special thanks to Dr. George Seidel, whose patience and teaching have given me a new understanding of statistics. To Tom McConnell, Ken Martin, and the WVU Extension Service for providing me with funds as well as experience. Dr. Barton Baker and the

Department of Plant and Soil Sciences for accepting me into the program and allowing me to achieve academic success so that I may go on to teach others the important lessons I have learned in my years at WVU. Lastly I would like to thank Sue Myers at the WVU Greenhouse, who provided me with the materials I needed in order to complete my experiments. 
TABLE OF CONTENTS

\begin{tabular}{|c|c|}
\hline & Page \\
\hline ABSTRACT & ii \\
\hline ACKNOWLEDGEMENTS & iii \\
\hline LIST OF FIGURES & vi \\
\hline LIST OF TABLES & vii \\
\hline CHAPTER 1: LITERATURE REVIEW & \\
\hline Organic Certification & 1 \\
\hline Organic Tomato Industry & 3 \\
\hline Tomato Transplant Production & 4 \\
\hline Growing Media Characteristics & 7 \\
\hline Types of Growing Media & 9 \\
\hline Compost as a Growing Medium & 11 \\
\hline Objectives of Study & 13 \\
\hline \multicolumn{2}{|l|}{ CHAPTER 2: MATERIALS AND METHODS } \\
\hline Plant Material & 15 \\
\hline Experimental Design & 15 \\
\hline Growing Media & 16 \\
\hline Watering Regimes & 17 \\
\hline Compost Tea & 18 \\
\hline Measurements & 19 \\
\hline Statistical Design & 20 \\
\hline
\end{tabular}




\begin{tabular}{|c|c|}
\hline \multicolumn{1}{|c|}{ CHAPTER 3: RESULTS } & \\
\hline Experiment 1 & 22 \\
\hline Experiment 2 & 25 \\
\hline Compost Tea Results & 28 \\
\hline CHAPTER 4: DISCUSSION AND CONCLUSIONS & 30 \\
\hline LITERATURE CITED & 56 \\
\hline
\end{tabular}




\section{LIST OF FIGURES}

\begin{tabular}{|c|c|c|}
\hline \multirow{2}{*}{\multicolumn{3}{|c|}{ EXPERIMENT 1}} \\
\hline & & \\
\hline 1 & $\begin{array}{l}\text { Shoot fresh weight in grams }(\mathrm{g}) \text { of } 4 \text {-week-old transplants grown in } \\
\text { conventional peat-lite (Hconv) and media containing composted horse } \\
\text { manure }(\mathrm{H} 100, \mathrm{H} 75, \mathrm{H} 50 \text { and } \mathrm{H} 25) \text { at watering regimes of } 80,100 \text {, } \\
120,150 \text {, and } 200 \text { percent container capacity. }\end{array}$ & 41 \\
\hline 2 & $\begin{array}{l}\text { Shoot dry weight in grams }(\mathrm{g}) \text { of } 4 \text {-week-old transplants grown in } \\
\text { conventional peat-lite }(\mathrm{Hconv}) \text { and media containing composted horse } \\
\text { manure }(\mathrm{H} 100, \mathrm{H} 75, \mathrm{H} 50 \text { and } \mathrm{H} 25) \text { at watering regimes of } 80,100 \text {, } \\
120,150 \text {, and } 200 \text { percent container capacity. }\end{array}$ & 42 \\
\hline 3 & $\begin{array}{l}\text { Change in electrical conductivity expressed in } \mathrm{dS}^{-1} \text { over time of } \\
\text { conventional peat-lite (Hconv) and media containing composted horse } \\
\text { manure (H100, } \mathrm{H} 75, \mathrm{H} 50 \text { and } \mathrm{H} 25) \text {. }\end{array}$ & 44 \\
\hline 4 & $\begin{array}{l}\text { Electrical conductivity of media expressed in } \mathrm{dS}^{-1} \text { after } 4 \text { weeks of } \\
\text { conventional peat-lite (Hconv) and media containing composted horse } \\
\text { manure }(\mathrm{H} 100, \mathrm{H} 75, \mathrm{H} 50 \text { and } \mathrm{H} 25) \text { at watering regimes of } 80,100 \text {, } \\
120,150 \text {, and } 200 \text { percent container capacity. }\end{array}$ & 45 \\
\hline 5 & $\begin{array}{l}\text { Change in pH of media over time of conventional peat-lite (Hconv) and } \\
\text { media containing composted horse manure (H100, H75, H50 and } \\
\mathrm{H} 25) \text {. }\end{array}$ & 46 \\
\hline & EXPERIMENT 2 & \\
\hline 6 & $\begin{array}{l}\text { Shoot fresh weight in grams (g) of 4-week-old transplants grown in } \\
\text { conventional peat-lite (Cconv) and media containing composted cow } \\
\text { manure (C100, C } 75, C 50 \text { and C25) at watering regimes of } 80,100 \text {, } \\
120,150 \text {, and } 200 \text { percent container capacity. }\end{array}$ & 48 \\
\hline 7 & $\begin{array}{l}\text { Shoot dry weight in grams }(\mathrm{g}) \text { of } 4 \text {-week-old transplants grown in } \\
\text { conventional peat-lite (Cconv) and media containing composted cow } \\
\text { manure (C100, C } 75, C 50 \text { and C25) at watering regimes of } 80,100 \text {, } \\
120,150 \text {, and } 200 \text { percent container capacity. }\end{array}$ & 49 \\
\hline 8 & $\begin{array}{l}\text { Change in electrical conductivity expressed in } \mathrm{dS}^{-1} \text { over time of } \\
\text { conventional peat-lite (Cconv) and media containing composted cow } \\
\text { manure (C100, C75, C50 and C25). }\end{array}$ & 51 \\
\hline 9 & 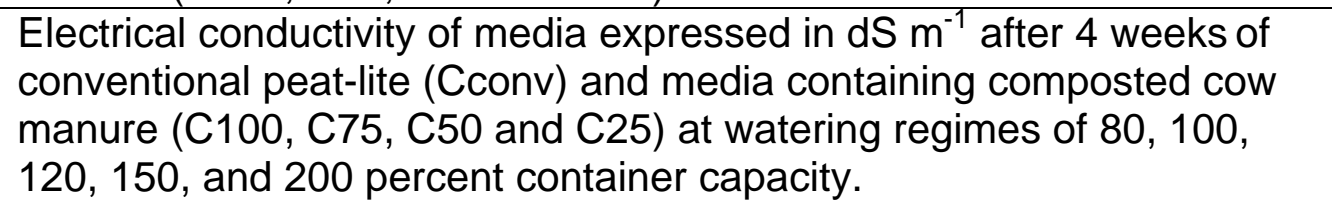 & 52 \\
\hline 10 & $\begin{array}{l}\text { Change in pH over time of conventional peat-lite (Cconv) and media } \\
\text { containing composted cow manure (C100, C75, C50 and C25). }\end{array}$ & 53 \\
\hline
\end{tabular}




\section{LIST OF TABLES}

\begin{tabular}{|c|l|c|}
\hline Table & \multicolumn{1}{|c|}{} & Page \\
\hline $\mathbf{1}$ & $\begin{array}{l}\text { The influence of the percentage of compost and peat-lite (v/v) on the } \\
\text { carbon (C), and nitrogen (N) content, as well as the carbon to nitrogen } \\
\text { ratio (C:N) of the growing media of Experiments 1 and 2. }\end{array}$ & $\mathbf{3 7}$ \\
\hline $\mathbf{2}$ & $\begin{array}{l}\text { Watering regime and amount of liquid applied per container to organic } \\
\text { and conventional treatments of Experiments 1 and 2. }\end{array}$ & $\mathbf{3 8}$ \\
\hline $\mathbf{3}$ & $\begin{array}{l}\text { Chemical characteristics of synthetic fertilizer, compost tea and tap } \\
\text { water used in watering regimes of Experiments 1 and 2. }\end{array}$ & $\mathbf{3 9}$ \\
\hline $\mathbf{4}$ & $\begin{array}{l}\text { Main effects (watering regime and media) and interaction of main } \\
\text { effects (watering regime x media) on dependent variables with } \\
\text { (conventional) and without (organic) conventional treatments of } \\
\text { Experiment 1. }\end{array}$ & $\mathbf{4 0}$ \\
\hline $\mathbf{5}$ & $\begin{array}{l}\text { Percentage of dry weight based on fresh weight (dry weight \%) of the } \\
\text { shoots of 4-week-old tomato transplants from Experiment 1. }\end{array}$ & $\mathbf{4 3}$ \\
\hline $\mathbf{6}$ & $\begin{array}{l}\text { Main effects (watering regime and media) and interaction of main } \\
\text { effects (watering regime x media) on dependent variables with } \\
\text { (conventional) and without (organic) conventional treatments of } \\
\text { Experiment 2. }\end{array}$ & $\begin{array}{l}\text { Percentage of dry weight based on fresh weight (dry weight \%) of the } \\
\text { shoots of 4-week-old tomato transplants from Experiments 2. }\end{array}$ \\
\hline $\mathbf{8}$ & $\begin{array}{l}\text { Main effects (watering regime, media and compost tea) and interaction } \\
\text { of main effects (watering regime x media x compost tea) on dependent } \\
\text { variables of Experiment 1. }\end{array}$ & $\mathbf{5 4}$ \\
\hline $\mathbf{9}$ & $\begin{array}{l}\text { Main effects (watering regime, media and compost tea) and interaction } \\
\text { of main effects (watering regime x media x compost tea) on dependent } \\
\text { variables of Experiments 2. }\end{array}$ & $\mathbf{5 5}$ \\
\hline
\end{tabular}




\section{CHAPTER 1}

\section{LITERATURE REVIEW}

\section{Organic Certification}

The organic farming industry is estimated to be one of the fastest growing segments of agriculture in the United States. The United States Department of Agriculture has observed that certified organic land has more than doubled between 1992 and 1997 and another million acres was added between 1997 and 2001. The strong market suggests that interest in organically produced agricultural goods will only continue to rise (Greene, 2001; Greene et al., 2001; Greene and Kremen, 2003).

The increase in consumers' demand for organic products over that last several decades coincided with an increase in the number of state and private institutions setting standards to support organic claims made by farmers. After recognizing the need to ensure the credibility of the small and growing organic industry, the California Certified Organic Farmers organization was formed in 1973 to become the first agency to begin third-party certification (USDA, 2002). By 1995 more than half of the states had laws or rules to manage the use of the term "organic" on foods marketed organically (Greene, 2001; Vandeman and Hayden, 1997). The various third-party certifying agents throughout the United States began to experience friction since each agency established different standards of organic production (USDA, 2002). 
The Federal government became involved in the organic industry with the passage of the Organic Foods Production Act, adopted as part of the 1990 Farm Bill (§§7 U.S.C. 6501-6522, 2003). This Act was implemented in order to initiate the creation of national organic standards that would create a definition of the term organic and facilitate marketing of organic commodities both internationally and within the United States (USDA, 2002). An agency within the United States Department of Agriculture, the Agricultural Marketing Service, published the final rule in December of 2002 in order to implement the Organic Foods Production Act of 1990 (USDA, 2002).

On October 21, 2002, after about a decade of development, the National Organic Program (NOP) (7 C.F.R. pt. 205, 2003) was established, implementing organic standards and requiring organic growers to become certified by an organization accredited under the NOP (Greene and Kremen, 2003; USDA, 2002).

The NOP has created a healthy and stable market for organic foods, where both consumers and producers of organic commodities benefit. Eliminating misconceptions about the term organic and providing an agreed upon definition of the term 'organic' was necessary to aid in communication and to promote the organic industry. Consumers' benefit from an efficient organic market and increased confidence that items purchased with the United States Department of Agriculture organic seal will prescribe to certain production standards (Greene and Kremen, 2003). 
Although the implementation of the Final Rule has had many benefits, there are still obstacles to the adoption of organic practices throughout the farming industry. Factors include an increase in the labor required for organic production (and the costs associated with it). Risk of incurring losses associated with shifting to organic methods, which may be unfamiliar to farmers. Higher costs incurred by organic farmers in order to certify their farm as organic (inspection fees and pesticide residue testing). Additionally, during the three-

year certification process farmers cannot obtain a premium price while converting from conventional to organic practices (Sellen et al., 1995; Duram, 1999; Greene, 2001; Greene and Kremen, 2003).

\section{Organic Tomato Industry}

Within the organic industry a larger proportion of vegetables are grown as compared to the amount grown under the conventional system. Approximately 2 percent of the U.S. certified cropland in 2001 was occupied by organic vegetables with tomatoes, lettuce, and carrots grown on one third of that land (Greene and Kremen, 2003). In 2001, one percent of organic acreage was planted to tomatoes. Organic growers generally sell fresh tomatoes directly to consumers through farmers' markets and are able to receive higher prices while bringing a sense of community to their area (Greene and Kremen, 2003).

A reason for the popularity of organic vegetables may be that they are generally eaten fresh allowing chemical residues used in conventional production to be ingested directly into the human system (Sellen et al., 1995; Greene, 2001). 
A shopper survey conducted in State College, PA in 1990 found that respondents were concerned about chemical residues on fresh tomatoes and the risks associated with them. These risks included risks to their personal health, as well as the effects of pesticides on farm workers, groundwater, wildlife, and the environment. Almost $26 \%$ of those surveyed were willing to pay more than $15 \%$ extra for tomatoes that were free of pesticide residues (Weaver et al., 1992).

\section{Tomato Transplant Production}

Like conventional tomatoes, organic tomatoes usually begin with the production of tomato transplants. Transplants are grown in containers in a greenhouse or other controlled environment before being placed in a field or in larger containers in the case of greenhouse production. Farmers use tomato transplants in order to achieve improved uniformity, higher plant survival in the field, higher early and total yields, and marketable fruit sizes (Liptay and Nicholls, 1993; Weston and Zandstra, 1989).

Growing plants in a container, as compared to an open field, requires more care and attention since there is a limited volume from which a plant can absorb nutrients and water (Biernbaum and Versluys, 1998). Factors that have been found to influence the development of tomato transplants in the greenhouse, and subsequent performance in the field include container size, age of the transplant, as well as fertilization and watering regimes.

Weston and Zandstra, (1986) found that although total yields were similar for transplants grown in various sized containers, transplants grown in larger cell 
sizes produced greater early yields. It is theorized that plants grown in cells with larger volumes were able to produce large root systems that did not suffer as much from transplant shock. The increased root growth is thought to be due to an increase in the volume of air and water available to the roots in the medium and not to the larger container (Tilt et. al, 1987).

Weston and Zandstra, (1989) also found that transplant age can have an effect on early and total fruit yield. Tomato transplants grown in the greenhouse for 4 and 5 weeks were found to be ideal for the production of greater early marketable yields and total fruit yields. It was believed that these transplants did not become root bound and were at a desirable maturity level to become established in the field earlier than 3-week-old transplants.

Several studies have also found that fertilization regimes can affect yields (Liptay and Nicholls, 1993; Weston and Zandstra, 1989). It was found that varying levels of potassium did not affect the performance of seedlings in the field and phosphorus was needed at low levels. Nitrogen levels were found to have the greatest effect on transplant performance in the field. Although at high $\mathrm{N}$ levels, root growth and early yields increased in the field, those transplants were not considered hardened enough to withstand weather conditions and had lower field survival (Liptay and Nicholls, 1993). Weston and Zandstra, (1989) found that although early yields were greater for transplants receiving moderate to high nitrogen levels, there was no an effect of nitrogen or phosphorus levels on total yields of tomatoes. 
Watering regime can also affect the growth of a transplant since the uptake of water from the root zone is required in order to transport nutrients throughout the plant, keep the plant cool in hot weather, and provide support through turgor pressure in the cells (Kreij, 1995). The availability of water to a tomato transplant is largely dependent on characteristics of the medium. If a plant is unable to take up enough water because the medium has poor waterholding capacities it can have negative effects on growth and overall health of the transplant (Biernbaum and Versluys, 1998; Fonteno et al., 1981). Since substrates physical characteristics can differ, the air and water holding capacities may differ as well. Therefore it is important to adjust the watering regime according to the medium, while also taking into account the temperature and humidity in the greenhouse (Biernbaum and Versluys, 1998).

Transplant growers usually apply high volumes of water to their plants since it is not well understood how much water is actually needed to maximize growth. Over-watering can reduce the nutrient concentration in the substrate (Groves et. al, 1998; Tyler et al., 1996). By decreasing the amount of water supplied to a transplant, less effluent including nitrate, ammonium and phosphorus is likely to leave the container and enter ground and surface waters. The absorption of nitrogen or phosphorus was unaffected by the watering regime but a reduction in water supplied to a transplant can result in a loss of total plant growth. It is for the grower to examine the trade off between whether a reduction in plant growth is worth a reduction in the amount of nutrients leaving the root zone that could potentially lead to groundwater pollution (Tyler et al., 1996). 


\section{Growing Media Characteristics}

A growing medium must possess important physical and chemical properties in order to provide a transplant with an environment suitable for growth. Physical parameters include the ability of the growing media to have adequate air and water holding capacities, a stable structure and a bulk density that is light enough for transportation while heavy enough to provide support to the transplant (Nelson, 1991; Raviv et al., 1986).

The distribution of particle and pore sizes in a growing medium will determine the watering-holding capacity of the substrate as well as the air content to allow adequate gas exchange between the roots of the plant and the atmosphere. Pores are open spaces between solid particles that are either full of air or water. Larger particle sizes will create large pores that remain filled with air shortly after irrigation (Paul and Lee, 1976). If a potting mix has too many large pores it generally needs to be watered more frequently since the media cannot retain enough water for plant uptake. Small particle sizes of a medium will create small pores that can hold water against gravity. A potting medium with too many small pores can become water logged reducing the ability of air and gas exchange (Kuepper and Adam, 2002). An acceptable growing medium will have a balance of both large and small pores.

Most growing media are made up of organic materials that continuously undergo decomposition. However, it is important to choose a substrate that is stable and its decomposition negligible. If organic aggregates in the substrate 
decompose it will lead to a decrease in aeration of the substrate. Additionally, a reduction of the substrate in the container could be detrimental to the plant since there is less space available to the roots to sustain growth (Nelson, 1991).

The stability of an organic growing medium can be measured by the carbon to nitrogen ratio (C:N) (Epstein, 1997). A C:N ratio below 20 is considered to be indicative of a compost that is no longer undergoing rapid microbial change and is stable (Epstein, 1997; Havlin et. al, 1999). If the C:N ratio is above 30 , any nitrogen added to the medium for plant growth will be utilized by microorganisms that will cause a reduction in its availability to the plant and also lead to a depletion of oxygen that is being used by the microorganisms (Raviv et al., 1986).

Growing media must also posses chemical characteristics to promote plant growth. These characteristics include adequate cation exchange capacity (CEC), $\mathrm{pH}$, and soluble salts level. Cation Exchange Capacity of organic matter has permanent negative charges that electrically attract and hold cations such as ammonium, potassium, and calcium. Cation nutrients are held to exchange sites and are readily available to plants for uptake (Rhoades, 1982). An adequate CEC can provide transplants with a reserve of nutrients that are gradually released to the transplant and are retained against leaching (Havlin, 1999).

Since the $\mathrm{pH}$ level of a growing medium can affect the form of a plant nutrient as well as the mineralization of nitrogen it is extremely important to a fertilization program (Argo, 1998). Most plant species prefer a growing medium that has a pH range of 5.0 to 6.0 (Kreij, 1995; Nelson, 1991). Above a pH level 
of 6 nutrients such as iron and phosphorus may become unavailable while below a $\mathrm{pH}$ level of 5 , potassium, calcium, and nitrogen may become unavailable (Raviv et al., 1986).

Measuring the electrical Conductivity (EC) of a medium will give an indication of the concentration of soluble salts in a medium. Since water flows by diffusion from areas of high to low concentrations, it is important not to have a medium with an EC level that is too high since it can inhibit the uptake of water into the plant and lead to desiccation of the plant cells (Nelson, 1991).

\section{Types of Growing Media}

Before the middle of this century when soil was the main component of a growing medium, the degradation of organic matter in the soil released nutrients available for plant growth. Additional organic and inorganic nutrients were added to transplants as soil tests indicated. As quality topsoil became harder to find, and associated problems of low aeration, disease organisms and weed seeds in the soil became an issue, soilless media began to take the place of soil (Kuepper and Adam, 2002). Drs. J.W. Boodley and R. Sheldrake of Cornell University introduced peat-lite mixes in the 1960's as a substitute for soil in potting mixes. These mixes are referred to as Mix A and Mix B. Mix A consists of equal volumes of peat and vermiculite (v/v), while Mix B substitutes perlite for vermiculite (Boodley and Sheldrake, 1982). In time, soil was replaced with peat as the main ingredient in the potting mix and nutrients were supplied via irrigation 
to transplants with synthetic inorganic fertilizers by a process known as fertigation (Nelson, 1991).

Sphagnum peat is formed from sphagnum moss as a result of partial decomposition of plants under anaerobic or semi-anaerobic conditions. Peat is formed in environments characterized by high precipitation, low evaporation as well as low temperatures during the summer months and low annual sunshine (Raviv et al., 1986).

Since the 1960s sphagnum peat moss has become one of the most commonly used materials of soilless media. There are several reasons for its popularity. Peat is widely available from countries where peat bogs are prevalent such as Canada, Ireland and Finland. Peat is a good growing medium because it is a stable organic material that decomposes very slowly. Due to the high surface area of the material that make up the cell walls, peat can hold a great deal of water, (up to $60 \%$ of its volume) and has a low bulk density as well as high CEC. Additionally, peat can hold large volumes of air and nutrients within its porous cell walls. Peat is also free of weed seeds as well as plant and animal pathogens. Peat, however has a low $\mathrm{pH}(3.0-4.0)$ that needs to be adjusted by adding finely ground limestone (dolomitic or calcitic) (Robertson, 1993) and does not contain nutrients requiring additional fertilization.

For several reasons there is a search for alternatives to the use of peat in growing media (Robertson, 1993). Peat can be costly, especially in countries such as Israel where there is not a local source and peat can account for $10-15 \%$ of total cost for pot plant production (Raviv et al., 1986). 
Peat bogs serve as wetland habitat for a variety of species as well as a sink for carbon dioxide. When peat is extracted, carbon can no longer accumulate and the deeper layers that would eventually turn to coal are exposed to aerobic degradation. After a peat bog is mined, it can take many decades before the bog can fix carbon dioxide at its original capacity (Raviv et al., 1998). It is believed to be important that peat extraction for use by the horticulture industry is reduced in order to protect the environment (Pryce, 1991) and reduce cost of transplant production.

The industry however, disagrees with conservationists over the impact that peat extraction has on resources in peat bogs. It is thought that the extraction of peat can be sustainable since peat formation exceeds the amount that is extracted for use. Additionally, adequate conservation and rehabilitation measures are in place to restore peat bogs that are cut up and extracted (Robertson, 1993).

\section{Compost as a Growing Medium}

Animal manure has been used as a source of nutrients for centuries (Kraus et al., 2000). However, with the advent of synthetic inorganic fertilizers made earlier in this century, the use of animal excreta as a fertilizer source has decreased dramatically, resulting in the designation of manure as a solid waste rather than a valuable resource (Hoitink and Boehm, 1999).

Additionally, livestock production has changed from pasture to animal feedlot systems. When animals are raised in open pasture the wastes generated 
are returned back to the land to add nutrients and organic matter to the soil. However, in animal feedlots, high concentrations of animals are raised and wastes accumulate at such high rates that they cannot be used on the land in the area where they are produced and must be transported elsewhere for disposal (Taiganides, 1977; Kraus et al., 2000). The decrease in the use of manure for fertilizers as well as an increase in animal feedlots has made the disposal of animal wastes problematic.

Composting has increased in popularity in order to recycle animal wastes and has led to an increase in its availability for use as a growing medium by the horticulture industry (Hoitink et al., 1991). Commercial growers using compost in a growing medium for transplant production cannot afford any losses due to lack of quality and consistency. It is important that composting facilities are able to produce composts that have the same performance and quality between batches so it can be used as a growing medium (Gouin, 1995; Ozores-Hampton et al., 1999; Robertson, 1993). Quality of the compost is dependent on how it is made as well as the materials used in the process. These parameters can impact the amount of nutrients in the composts as well as the chemical and physical properties of the end product (Kuepper and Adams, 2002).

Currently, tomato transplant production is based on conventional production methods that use a peat-based growing medium in combination with synthetic inorganic fertilizers. As more tomato growers become organically certified the need for organic production methods to produce quality tomato transplants will need to be improved (Raviv et al., 1998). Since synthetic 
fertilizers are not allowed under organic production, organic tomato transplant growers must find alternative organic methods of supplying nutrients to their transplants.

Using compost to reduce or replace peat in a potting mix to grow organic tomato transplants could potentially supply a slow-release form of nutrients to the transplant and replace the use of synthetic fertilizers not allowed under an organic system (Corti et al., 1998; Ozores-Hampton et al., 1999). However, since the release of nutrients from compost is dependent on the rate of decomposition, additional fertilization may be necessary for plant growth (Eklind et al., 2001; Kraus et al., 2000). Watering regimes may also need to be adjusted since many composted materials have been found to have lower water retention and buffering capacities than peat-based media (Corti et al., 1998; Raviv and Shlomit, 1997).

Using compost in potting mixes may not only benefit organic tomato transplant growers by providing them with an alternative fertilizer source but its use can also provide an alternative to the disposal and distribution of waste as well as decrease the use of peat in growing media.

\section{The objectives of this research were to test the following hypotheses:}

1. Growing media consisting of various ratios of composted manure and peatlite will produce organic tomato transplants with comparable growth characteristics as transplants grown in a conventional peat-lite mix, fertilized with synthetic fertilizers. 
2. Growing media consisting of various ratios of composted manure and peatlite will effect the growth of tomato transplants.

3. The watering regime will affect the growth of organic tomato transplants.

4. Compost tea can be used as an additional organic fertilizer source in order to increase the growth of organic tomato transplants. 


\section{CHAPTER 2}

\section{MATERIALS AND METHODS}

\section{Plant Material}

Two experiments, Experiment 1 and Experiment 2, were conducted in the spring and summer of 2003. Tomato (Lycopersicon esculentum cv. WV ‘63) seeds were sown in 288-cell $\left(<6 \mathrm{~cm}^{3}\right.$ volume) plug trays in a soilless peat-lite medium mix (1 peat : 1 perlite by volume) on 28 Mar, 2003 for Experiment 1 and on 12 June 2003 for Experiment 2. The trays were placed in a mist bed with a bottom heat set at $29^{\circ} \mathrm{C}$ and misting controlled by an electric leaf (Phytotronics, Inc., Earth City, MO). After 26 days in the mist bed the seedlings from Experiment 1 were transplanted into $229 \mathrm{~cm}^{3}$ square pots with about $175 \mathrm{ml}$ of medium. In Experiment 2, tomato seedlings were transplanted into cell packs each measuring $348 \mathrm{~cm}^{3}$ also with about $175 \mathrm{ml}$ of medium. The transplants were grown in the West Virginia University greenhouse in Morgantown, WV (lat. $39^{\circ} 39^{\prime} \mathrm{N}$ and long. $\left.79^{\circ} 55^{\prime} \mathrm{W}\right)$ at $22^{\circ} \mathrm{C}(\mathrm{D} / \mathrm{N})$ for an additional 4 weeks.

\section{Experimental Design}

To test the hypothesis that the ratio of compost as well as the watering regime can affect the quality of organic transplants, Experiment 1 and 2 were set up to compare transplants grown under organic production methods to conventional production methods.

Experiment 1 consisted of a $3 \times 5 \times 8$ factorial randomized complete block design with three replicate blocks. Each block Included plants to be measured 
on weeks 2,4 , and 6 , with five media and 8 watering regimes. The first experiment was intended to last 6 weeks but was ended early since the transplants reached marketable size at week 4 .

Experiment 2 was established using a $2 \times 5 \times 8$ factorial randomized complete block design with three replicate blocks. Each block included plants to be measured on weeks 2 and 4 , with 5 media and 8 watering regimes.

\section{Growing Media}

Five growing media were used to produce tomato transplants. These media were composed of peat, perlite, and compost in different ratios $(\mathrm{v} / \mathrm{v})$. Media containing $100 \%$ peat-lite were the conventional treatments. Four organic treatments contained $100,75,50$ and $25 \%$ composted animal manure with the remaining percentage consisting of a peat-lite mix by volume (Table 1).

The peat-lite mix used in this study was made by mixing together 110 liters of sphagnum peat moss (Premier Horticulture Inc. Redhill, Pa) and $10 \mathrm{~kg}$ of coarse horticultural perlite (Therm-o-rock East Inc. New Eagle, Pa). Dolomitic limestone (derived from calcium-magnesium limestone) was added to the peatlite mix in Experiment 1 to adjust the $\mathrm{pH}$ to approximately 5.7. In the second experiment dolomitic limestone was only added to the conventional and C25 treatments since the $\mathrm{pH}$ of the composted cow manure (Southern States, Morgantown, WV, Fafard, Agawam, MA) was high enough to compensate for the low $\mathrm{pH}$ of the peat-lite mix. 
The composted horse manure (Seneca Way, Bruceton Mills, WV) had a nutritional analysis of $0.25 \mathrm{~N}-0.14 \mathrm{P}-0.20 \mathrm{~K}$. The compost consisted of horse manure, sawdust, urine and hay. Seneca Way produced their compost by forming windrows $3.7 \mathrm{~m}$ wide by $1.8 \mathrm{~m}$ tall. The windrows were watered to $50 \%$ moisture and turned every 2 weeks for 3 months. Foreign objects were screened out before sale to create a more consistent product (Kirby Clark, 3/1/03, personal communication).

The composted cow manure had a nutritional analysis of 1.0N-1.0P-1.0K. The compost consisted of cow manure, peat moss, peat humus, urine, and bedding materials. The raw materials were placed in closed tunnels on concrete slabs. Air was forced through the pile and maintained at $70^{\circ} \mathrm{C}$ for 3 weeks. The compost was taken out of the tunnel and placed in windrows on cement slabs for 1 week to finish maturation. During this time the piles were turned several more times (Edward Catellier, 6/1/03, personal communication).

\section{Watering Regimes}

Five of the eight watering regimes were achieved by adding water to each pot when the surface was dry in an equal amount to $80,100,120,150$, and $200 \%$ of the respective container capacities of each medium (Table 2). The remaining three watering regimes included compost tea and were added only to organic treatments on specific weeks depending on watering regime. Container capacities were determined by adding water to individual containers holding the various air-dried growing media. When water first dripped through the bottom of 
the container it was determined to be at container capacity. Container capacity is defined as the amount of water remaining in the medium after drainage against gravity. The watering regime did not change and each transplant received the same amount of liquid throughout each experiment. Transplants were checked two times a day and watered when needed using a beaker to measure the correct amount of liquid.

Transplants grown in the conventional peat-lite mix received $100 \mathrm{ppm} \mathrm{N}$ of a synthetic 20-10-20 water-soluble fertilizer (Greencare, Kankakee, IL).

Transplants grown in potting mixes containing composted animal manure were watered with tap water. Transplants of Experiment 1 received compost tea made from composted horse manure and transplants of Experiment 2 received compost tea made from composted cow manure.

\section{Compost Tea}

A bucket method was used to prepare the compost tea in both experiments (Ingham, 2002). Nine hundred grams of composted horse manure or $2300 \mathrm{~g}$ of composted cow manure were added to separate 18-L buckets containing $14 \mathrm{~L}$ of water. The compost tea used in Experiment 1 and Experiment 2 was prepared so as to produce a tea with an EC comparable to the synthetic liquid fertilizer (Table 3).

Weighted bubbler tubes at the bottom of the bucket allowed air to flow to the bottom of the container. An aquarium pump (Hi-Tech Pump-380, Ethical Products, Newark, NJ) was used to aerate the compost tea by supplying 
a continuous flow of air through the bucket at $1000 \mathrm{ml} \cdot \mathrm{min}^{-1}$. The tea was aerated for 48 hours.

A preliminary experiment indicated that at high watering regimes there was a decrease in the EC of the medium. It was hypothesized that adding compost tea could replace nutrients lost due to leaching and increase plant growth. Treatments with higher watering regimes received compost tea earlier than treatments with lower watering regimes. At the highest watering regime of $200 \%$ compost tea was added during week 1 . At the $150 \%$ watering regime level transplants received compost tea on week 2 . At the $120 \%$ watering regime level transplants received compost tea at week 3.

\section{Measurements}

Tissue analysis. Tomato transplant shoots were cut at the medium line and weighed to determine fresh weight. Shoots were oven-dried at $70^{\circ} \mathrm{C}$ for 2 days to determine shoot dry weight. On week 4, dried leaves of tomato transplants were separated from the stem by hand, ground with a mortar and pestle and $0.2 \mathrm{~g}$ of the sample was weighed and placed in a CNS -2000 elemental analyzer (LECO corp. St. Joseph, Michigan) to determine carbon and nitrogen content.

Media Analysis. EC and $\mathrm{pH}$ of the media were analyzed with an Ultrameter 6P EC and pH meter (Myron L. Co., Carlsbad, Ca) using the 2:1 method. The 2:1 method uses 1 part medium to 2 parts distilled water in order to obtain $\mathrm{EC}$ and $\mathrm{pH}$ readings. After the plant was cut at the base the roots were 
separated from the medium. The medium was then mixed and 3 separate random samples were taken. One part of medium was added to 2 parts of distilled water. After mixing, the solution was strained and the liquid was added to the Ultrameter $6 \mathrm{P}$ for testing.

Carbon and nitrogen concentrations of the media were determined by taking three samples of each medium and grinding with a mortar and pestle. After each medium was ground $0.2 \mathrm{~g}$ was placed in a CNS - 2000 elemental analyzer with $1 \mathrm{~g}$ of Comcat (LECO corp. St. Joseph, Michigan) to accelerate burning of the sample.

\section{Statistical Analysis}

To test the hypothesis that the ratio of composted manure in the potting mix and the watering regime will affect the quality of organic tomato transplants in comparison to conventional tomato transplants the following analysis were performed (SAS software, SAS Institute, Cary, NC):

Measurements of fresh and dry weights of the shoots, carbon and nitrogen content of the leaf tissue and EC of the media were analyzed on week 4 by a two-way ANOVA procedure with means separated by Duncan's Multiple Range Test. This analysis was repeated with and without conventional treatments under five watering regimes. The percentage of dry weight in the shoots received the same analysis but was measured only with the conventional treatments. 
A final analysis of fresh and dry weight of shoots, nitrogen content of the leaves, and the EC of the medium at week 4 were analyzed by one-way ANOVA with means separated by Duncan's Multiple Range Test.

The effect of compost tea was analyzed separately on the fresh and dry weight of shoots and the EC of the media. A three-way ANOVA procedure analyzed measurements from week 4 and included treatments with and without compost tea under 3 watering regimes and 4 organic media.

The influence of time was analyzed by ANOVA to determine the overall linear or quadratic change in $\mathrm{EC}$ and $\mathrm{pH}$ for each medium over 4 weeks. 


\section{CHAPTER 3}

\section{RESULTS}

\section{Experiment 1}

\section{Tissue Analysis}

Fresh and dry weight: After 4 weeks, the interaction of the watering regime and medium had a significant effect on the fresh and dry weights of the tomato transplant shoots (Table 4). However, when the interaction was analyzed without the conventional treatments, it was no longer significant for fresh weight but was significant for the dry weight of the shoots of the tomato transplants (Figures 1 and 2).

Medium affected the fresh and dry weight of the tomato transplant shoots with and without the conventional treatments included in the analysis (Table 4). The shoots of the transplants grown in the $\mathrm{H} 100$ medium was significantly greater than shoots of transplants grown in the conventional medium. Transplants grown in the $\mathrm{H} 75$ medium had comparable fresh and dry weights to the conventional medium. As the amount of peat-lite increased in the organic medium there was a significant decrease in the shoot fresh and dry weight of the tomato transplants. Watering regime also affected fresh and dry weight of the tomato transplant shoots with and without the conventional treatments included in the analysis (Table 4). At the lower watering regimes of $80-120 \%$ of container capacity, the fresh and dry weights of the tomato transplant shoots were significantly higher than shoots grown under the higher watering regimes of 150$200 \%$. 
Dry weight as a percentage of fresh weight: After 4 weeks, the watering regime and the ratio of composted horse manure in the media also did not affect the amount of dry weight in the shoots of the tomato transplants as a percentage of fresh weight (Table 5). However, tomato transplants grown in the conventional medium had significantly smaller percentages of dry weight than the organic treatments.

Carbon content of leaf tissue: After 4 weeks, the interaction of the watering regime and medium was not significant with and without the conventional treatments included in the analysis (Table 4). Medium affected the percentage of carbon in the leaf tissues of tomato transplants and was significantly highest in transplants grown in conventional medium. In general, there was a decrease in carbon content as the amount of peat-lite increased in the media, although this observation was not always statistically significant. Watering regime did not affect the content of carbon in the leaves of the tomato transplants (Table 4).

Nitrogen content of leaf tissue: After 4 weeks, the interaction of the watering regime and medium on the content of nitrogen in the leaf tissue was significant when conventional treatments were included in the analysis (Table 4). However, when the interaction was analyzed without the conventional treatments, it was not significant. Medium affected the content of nitrogen in the leaf tissue of the tomato transplants (Table 4). Tomato transplants grown in the conventional medium contained significantly higher amounts of nitrogen in the plant tissue than treatments grown in media containing composted horse 
manure. Nitrogen content in the leaves of the tomato transplants was significantly higher in the $\mathrm{H} 100$ medium and similar in the remaining organic treatments. Watering regime did not affect the content of nitrogen in the leaves of the tomato transplants (Table 4).

\section{Media Analysis}

Electrical Conductivity: The EC of the conventional medium increased linearly over a period of 4 weeks (Figure 3). The EC of the organic media decreased linearly for the organic media although the decrease was not significant for the $\mathrm{H} 25$ and $\mathrm{H} 50$ media.

After 4 weeks, the interaction of the watering regime and medium on the EC of the medium was significant when conventional treatments were included in the analysis (Table 4, Figure 4). However, when the interaction was analyzed without the conventional treatments, it was not significant. Medium affected the EC of the media (Table 4). Conventional medium had higher EC measurements than the organic media containing composted horse manure. $\mathrm{H} 100$ and $\mathrm{H} 75$ media had similar EC measurements and were significantly higher than the other organic media, which decreased with the addition of the peat-lite mix. The watering regime affected the EC of the media (Table 4). The EC of the media was significantly higher at the lowest watering regime of $80 \%$, and significantly lower at the highest watering regime of $200 \%$.

$\mathrm{pH}$ of media treatments: All media of Experiment 1 had a statistically significant quadratic change in $\mathrm{pH}$ over the 4-week period (Figure 5). The 
conventional medium had a decrease in $\mathrm{pH}$ by the end of four weeks while there was an increase in the $\mathrm{pH}$ of the organic media.

\section{Experiment 2}

\section{Tissue Analysis}

Fresh weight: After 4 weeks, the interaction of the watering regime and medium had a significant effect on the fresh and dry weights of the tomato transplant shoots with and without the conventional treatments included in the analysis (Table 6). Transplants grown in the $\mathrm{C} 100$ medium had significantly smaller fresh and dry weights under the $150-200 \%$ watering regime than any other transplant grown in any of the other media types under any of the five watering regimes (Figures 6 and 7). Medium affected the fresh and dry weight of the shoots of the tomato transplants (Table 6). The shoots of tomato transplants grown in the conventional medium had significantly higher fresh and dry weight than the shoots of transplants grown in organic media. Transplants grown in the C50 and C75 media had similar fresh and dry weights to one another and were significantly higher than transplants grown in the C100 and C25 media. Although the watering regime had a significant effect on the fresh and dry weight of the shoots of the tomato transplant, means tended to be similar as determined by Duncan's Multiple Range Test (Table 6).

Dry weight as a percentage of fresh weight: After 4 weeks, watering regime did not affect the percentage of dry weight in the shoots of the tomato transplants. However, medium did affect the percentage of dry weight in the 
shoots of the tomato transplants (Table 7). C100 and C75 media had significantly higher percentages of dry weight and tended to decrease as the amount of peat-lite increased in the growing media, although this trend was not always significant.

Carbon content of leaf tissue: After 4 weeks, the interaction of the watering regime and medium was not significant with and without the conventional treatments included in the analysis (Table 6). Medium affected the fresh and dry weight of the shoots of the tomato transplants (Table 6). Tomato transplants grown in the $\mathrm{C} 25$ medium showed smaller amounts of carbon in the leaf tissue than any of the other media treatments. Watering regime did not have a significant effect on the carbon content in the leaf tissue of tomato transplants (Table 6).

Nitrogen content of leaf tissue: After 4 weeks, the interaction of the watering regime and medium had a significant effect on nitrogen content in the leaves of the tomato transplants with and without the conventional treatments included in the analysis (Table 6). Medium affected the nitrogen content in the leaves of the tomato transplants (Table 6). Nitrogen content was higher in the leaves of transplants grown in the conventional medium than tomato transplants grown in media containing composted cow manure. Transplants grown in C50 and C75 media contained higher amounts of nitrogen in their leaves than $\mathrm{C} 100$ and C25 media. Watering regime affected the amount of nitrogen found in the leaves of the tomato transplants and tended to decrease as the watering regime increased, although the trend was not always significant (Table 6). 


\section{Media Analysis}

Electrical Conductivity: There was a quadratic change in EC over the 4week study for all media types except for the C75 medium treatment, which did not show a significant change in EC (Figure 8). While the conventional medium had an overall increase in EC over the 4-week trial, the organic media had an overall decrease in EC.

After 4 weeks, the interaction of the watering regime and medium had a significant effect on the EC of the media with and without the conventional treatments included in the analysis (Table 6). The EC of the $\mathrm{H} 100$ medium at the $150-200 \%$ watering regime had a significantly larger decrease in EC by week 4 than any of the other organic treatments (Figure 9). Medium affected the EC of the media and was highest in the $\mathrm{C} 100$ and $\mathrm{C} 75$ organic media and lowest in the conventional medium (Table 6). Watering regime affected the EC of the medium and was significantly highest under the $80 \%$ watering regime and tended to decrease as the watering regime increased, although this trend was not always significant (Table 6).

$\mathrm{pH}$ of media treatments: Conventional medium as well as $\mathrm{C} 100$ and $\mathrm{C} 75$ media showed a linear change in $\mathrm{pH}$ over the 4-week experiment (Figure 10). Like Experiment 1, a decrease in $\mathrm{pH}$ was observed in the conventional medium whereas the organic media increased. 


\section{COMPOST TEA RESULTS}

The interaction of compost tea, watering regime and medium was not statistically significant in any measurements in Experiments 1 or 2 (Tables 8 and 9). The interaction of watering regime and medium was also not significant for any of the measurements in Experiment 1 or 2. Therefore, the response of the dependent variables to the addition of compost tea was not significant. The following results only discuss the effects of watering regime and medium on fresh and dry weight of the shoots of the tomato transplants and the EC of the medium.

\section{Experiment 1}

\section{Tissue Analysis}

Fresh and dry weight: The fresh and dry weight of the tomato transplant shoots significantly decreased as the amount of peat-lite increased in the growing media (Table 8). The fresh of the shoots of the tomato transplants was significantly highest under the $80 \%$ watering regime. The dry weight of the tomato transplant shoots significantly decreased as the watering regime increased.

\section{Media Analysis}

Electrical Conductivity: EC of the media decreased as the as the amount of peat-lite increased in the media and as the watering regime increased (Table 8). 


\section{Experiment 2}

Tissue Analysis

Fresh and dry weight: Tomato transplant shoots grown in C75 and C50 media had fresh and dry weights that were significantly higher than those grown in C100 or C25 while transplants grown in C100 medium had significantly lower fresh and dry weights than any other transplant grown in the other media (Table 9). Unlike in Experiment 1, watering regime did not have a significant effect on the fresh or dry weight of the shoots of tomato transplants.

Media Analysis

Electrical Conductivity: The EC of the media was significantly lower in the C25 medium and in media under the $200 \%$ watering regime (Table 9). 


\section{CHAPTER 4 \\ DISCUSSION}

This study found that media with $100 \%$ and $75 \%$ composted horse manure and $75 \%$ and $50 \%$ of composted cow manure with the remainder peatlite can produce quality organic transplants for use by organic tomato growers. It was also shown that the amount of water supplied to organic transplants grown in composted manure while in the greenhouse is a key factor in producing quality transplants.

The chemical analysis and EC of the composted horse manure indicated that sufficient nutrients might have been present to support growth in most crops (Nelson, 1991). It was clear that as the amount of peat-lite in the media and the watering regime increased the EC levels decreased and may have contributed to decreased plant growth. Opposite trends were found in a study by OzoresHampton et al. (1999). In that study it was found that shoot as well as root dry weight decreased as the amount of composted yard trimming-biosolids increased in a medium with peat and vermiculite after 21 and 28 days. The reduction in growth was attributed to the high EC measurements of the compost and the addition of peat and vermiculite reduced the EC to optimal levels of 0 to $2 \mathrm{dS} \cdot \mathrm{m}^{-1}$. After 35 days differences between transplants disappeared and yield was similar regardless of the ratio of the compost, peat and vermiculite in the media. EC measurements only give an indication of the amount of soluble salts present in the compost. Although EC measurements were similar to the composted horse 
manure, the compost used in Ozores-Hampton's et al. (1999) study may have consisted of salts that were not essential for plant growth or were at toxic levels.

Transplants grown in media containing 100\% composted cow manure at the $150-200 \%$ watering regime showed the lowest fresh and dry weights.

Composted cow manure had high EC levels at the beginning of the experiment when the transplants were not able to utilize the soluble nutrients and may have been exposed to salt stress. By the end of the experiment at the higher watering regimes of $150-200 \%$ EC levels were reduced at levels lower than most other media containing composted cow manure. The high EC at the beginning of the experiment combined with the large reduction in EC may have led to a reduction in plant growth observed in our study. In support of this observation, Bugbee (1994) found that young transplants or seedlings are not large enough to utilize nitrogen in the beginning of their experiment and more was leached in media containing $100 \%$ composted material than media that included peat-lite resulting in decreased growth throughout the experiment.

Although EC levels were higher in media containing composted cow manure as compared to the conventional treatments, the fresh and dry weights of transplants grown in the composted cow manure were smaller than transplants grown in the conventional medium. One of the reasons transplants were smaller in composts containing composted cow manure is the possible presence of unusable nutrients (e.g. $\mathrm{Na}^{+}$) and associated salt stress.

Though tomato transplants grown in the conventional peat-lite media usually had higher fresh and dry weight, transplants grown in the organic media 
treatments had higher amounts of dry weight as a percentage of fresh weight than the conventional treatments. The amount of dry matter in the transplants could have an effect on the growth of transplants once they are placed in the field since dry matter content in the shoot of a plant is an important factor associated with good rooting and stress avoidance at transplanting (Markovic et al., 1997). According to Markovic et al. (1997) a dry matter content of tomato seedlings ranging from 8.1 to $12.7 \%$ is considered normal. All tomato transplants in this study had normal or above normal amounts of dry matter content of between 9.0 and $16.0 \%$ (see figures 5,6 and tables 9,10 ). Although the fresh and dry weights of the conventional treatments were generally higher than the organic treatments, the similarity in dry matter content may indicate that the quality of the organic transplants is comparable to the conventional transplants in these regards.

Generally, transplants from both experiments had carbon contents of around $40 \%$, which is considered normal for most plants (Nelson, 1991). Carbon is assimilated into plants from $\mathrm{CO}_{2}$ through photosynthesis and is used to synthesize carbohydrates, which is then utilized by the plants for various functions. The amount of carbon generally decreased with increasing amounts of peat-lite in the mix but generally was not affected by the watering regime similar to dry weight content observations. In addition to the above-mentioned reasons for lower fresh and dry weights, the decreasing amounts of nitrogen in the media, which are needed by the transplants for the formation of chlorophyll, may have 
also contributed to a decrease in photosynthesis and the synthesis of carbohydrates.

The concentration of nitrogen in the leaves of tomato transplants was significantly higher in the conventional peat-lite medium receiving synthetic fertilizers when compared to transplants grown in composted manure confirming observations by others (Eklind et al., 2001). In at least one other study, reduction in mineral content, including nitrogen of the leaves was attributed to the lower water holding capacity of composts in comparison to peat (D'Angelo et al., 1995).

Nitrogen content considered adequate in the dry tissue of most plants is considered to be about $1.5 \%$ (Salisbury and Ross, 1985). In this study the tomato transplants that were grown in media containing composted manure had between 2.5 and $1.3 \%$ of nitrogen in their leaves compared to 4.7 to $6.6 \%$ in the conventional treatments. The conventional treatments may have contained higher levels of nitrogen in their leaves but may not have been necessary for growth.

A C:N ratio below 20 is considered to be indicative of a compost that is no longer undergoing rapid microbial change and is stable (Epstein, 1997; Havlin et. al, 1999). The conventional medium had the highest $\mathrm{C}: \mathrm{N}$ ratio compared with the composted manure media. As the amount of peat-lite increased in the media the $\mathrm{C}: \mathrm{N}$ ratio also increased as a result of the decrease in nitrogen content in the media. The relatively lower C:N ratios of potting mixes containing 50,75 , or $100 \%$ composted manure indicated that nitrogen could be mineralized. However other studies have shown that the mineralization may not be enough to release 
sufficient nitrogen into the medium and media containing composted manure may therefore still require additional fertilization (Kraus et al., 2000). The conventional peat-lite medium along with the media containing only $25 \%$ of composted manure had $\mathrm{C}: \mathrm{N}$ ratios that could cause nitrogen immobilization. However, the stability of the peat which is made up of materials high in cellulose and lignin will take longer to decompose and may not lead to immobilization (Epstein, 1997; Freeman and Cawthon, 1999).

Throughout the 2 experiments $\mathrm{pH}$ levels remained between 5 and 8 , an acceptable range for plant growth (Nelson, 1991). The conventional treatment had a slight decrease in $\mathrm{pH}$ by the end of four weeks likely due to the slightly acidic fertilizer used in our study. The organic media had a slight increase in the $\mathrm{pH}$ by the end of the 4-week experiments, which may have been due to the slightly alkaline tap water.

As increasing amounts of composted manure were added to the peat-lite mix the $\mathrm{pH}$ of the media increased as well, due to the high $\mathrm{pH}$ level of the composted manure. The higher $\mathrm{pH}$ levels of the composted manure could reduce or eliminate the need to adjust the $\mathrm{pH}$ of a medium with dolomitic limestone when adding compost to a peat-lite mix. In general, $\mathrm{pH}$ was not affected by the watering regime.

According to Dr. Elaine Ingham's (2002) compost tea brewing manual, applying compost tea as a soil drench can create a barrier around the roots of plants of beneficial microorganisms as well as nutrients. Additionally, nutrient cycling can be improved as well as nutrient retention and disease suppression. 
In our study compost tea was not an effective fertilizer since it did not significantly increase the overall growth of the tomato transplants. However, we cannot exclude that compost tea helped in disease suppression because we did not measure any parameters associated with alleged characteristics of compost teas. There are other alternative fertilizer options not investigated here, an organic grower can use to supply additional nutrients to their transplants, such as blood, feather, crab-shell and cottonseed meal, as well as whey sludge. These products have shown to increase dry weight of tomato transplant shoots by 5783\% (Gagnon and Berrouard, 1993).

\section{Conclusion}

With the increasing availability of composted animal wastes and the importance of using organic management techniques in organic transplant production, organic growers are becoming increasingly interested in using compost as a potting medium. Our study and experiments by others have shown that composts can be a viable alternative to conventional transplant production (Corti et al., 1998; Ozores-Hampton et al., 1999; Raviv et al., 1998).

However it is important for producers of compost to supply a product that is consistent as well as of high quality so that organic producers will want to purchase their products for their potting mixes. Producers marketing their tomato transplants as organic must comply with the National Organic Programs guidelines when using compost in their potting mix (USDA, 2002). Transplant growers are interested in a compost that contains all the qualities of a good 
potting medium such as high nutrient content, an adequate and especially not too high of a $\mathrm{pH}$, an acceptable soluble salts level, a C: $\mathrm{N}$ ratio below 20 , and an acceptable water holding capacity (Ozores-Hampton et al., 1999).

This study was able to show that composted horse and cow manure can be used to replace or reduce the use of peat in the growing medium used for the production of organic tomato transplants. The ratio of compost used will depend on both physical factors of the medium such as water holding capacity and chemical factors that include $\mathrm{pH}$, as well as the amount and type of soluble salts in the medium. It is also important for a grower to manage the amount of water supplied to the tomato transplants since this could lead to a reduction in growth. Compost tea as used in this study is not recommended as an additional fertilizer source since it not increase the quality of the tomato transplants. 
Table 1. The influence of the percentage of compost and peat-lite (v/v) on the carbon (C), nitrogen (N) content, and carbon to nitrogen ratio (C:N) of the growing media of Experiments 1 and 2.

\begin{tabular}{|c|c|c|c|c|c|}
\hline Medium ${ }^{y}$ & Compost & Peat-lite & C (\%) & $N(\%)$ & C:N \\
\hline \multicolumn{6}{|c|}{ Expt. 1} \\
\hline Hconv & 0 & 100 & 34 & 0.7 & 50 \\
\hline-25 & 25 & 75 & 33 & 0.1 & 31 \\
\hline $\mathrm{H} 50$ & 50 & 50 & 30 & 1.6 & 20 \\
\hline-175 & 75 & 25 & 27 & 1.6 & 17 \\
\hline 100 & 100 & 0 & 29 & 2.0 & 14 \\
\hline \multicolumn{6}{|c|}{ Expt. 2} \\
\hline Conv & 0 & 100 & 39 & 0.6 & 62 \\
\hline $\mathrm{C} 25$ & 25 & 75 & 40 & 1.5 & 27 \\
\hline 50 & 50 & 50 & 40 & 2.0 & 20 \\
\hline 075 & 75 & 25 & 38 & 2.3 & 17 \\
\hline C100 & 100 & 0 & 38 & 2.5 & 15 \\
\hline \multicolumn{6}{|c|}{$\begin{array}{l}\mathrm{y} \text { Treatment names of } \mathrm{Hconv}, \mathrm{H} 100, \mathrm{H} 75, \mathrm{H} 50 \text {, and } \mathrm{H} 25 \\
\text { contain composted horse manure and treatment names of } \\
\mathrm{Cconv}, \mathrm{C} 100, \mathrm{C} 75, \mathrm{C} 50 \text {, and } \mathrm{C} 25 \text { contain composted cow } \\
\text { manure. Hconv and } \mathrm{Cconv} \text { are the conventional treatments } \\
\text { and } \mathrm{H} 100, \mathrm{H} 75, \mathrm{H} 50, \mathrm{H} 25, \mathrm{C} 100, \mathrm{C} 75, \mathrm{C} 50 \text {, and } \mathrm{C} 25 \text { are } \\
\text { the organic treatments. }\end{array}$} \\
\hline
\end{tabular}


Table 3. Chemical characteristics of synthetic fertilizer, compost tea and tap water used in watering regimes of Experiments 1 and 2.

\begin{tabular}{lcc}
\hline \hline Type of liquid & $\begin{array}{c}\text { Electrical } \\
\text { conductivity } \\
\left.\text { (dS } \mathrm{m}^{-1}\right)\end{array}$ & $\mathrm{pH}$ \\
\hline Composted horse manure & & \\
tea & 0.80 & 7.08 \\
Composted cow manure tea & 1.00 & 7.32 \\
Synthetic fertilizer & 1.00 & 6.28 \\
Tap water & 0.30 & 7.38 \\
\hline \multicolumn{3}{c}{ See table 2 for explanation of watering regimes. }
\end{tabular}


Table 4. Main effects (watering regime and media) and interaction of main effects (watering regime $x$ media) on dependent variables with (conventional) and without (organic) conventional treatments of Experiment $1(n=3){ }^{2}$

\begin{tabular}{|c|c|c|c|c|c|c|}
\hline & \multicolumn{6}{|c|}{ "Dependent variables } \\
\hline & $\begin{array}{c}\text { Fresh } \\
\text { weight }(g)\end{array}$ & $\begin{array}{c}\text { Dry } \\
\text { veight }(g)\end{array}$ & $\begin{array}{c}\text { Carbon } \\
\text { content } \\
(\%)\end{array}$ & $\begin{array}{c}\text { Nitrogen } \\
\text { content } \\
(\%)\end{array}$ & $\begin{array}{l}\text { Electrical } \\
\text { conductivity } \\
\left(\mathrm{dS} \mathrm{m}^{-1}\right)\end{array}$ & $\mathrm{pH}$ \\
\hline \multicolumn{7}{|l|}{ Watering regime } \\
\hline 80 & $12.2 \mathrm{a}^{\mathrm{y}}$ & $1.3 \mathrm{a}$ & 39 a & $1.7 \mathrm{a}$ & $0.4 \mathrm{a}$ & $6.4 \mathrm{~b}$ \\
\hline 100 & $11.8 \mathrm{a}$ & $1.3 a$ & 39 a & $1.6 \mathrm{a}$ & $0.3 \mathrm{~b}$ & $6.4 \mathrm{ab}$ \\
\hline 120 & $11.4 \mathrm{a}$ & $1.2 \mathrm{a}$ & 39 a & $1.8 \mathrm{a}$ & $0.3 \mathrm{~b}$ & $6.4 \mathrm{~b}$ \\
\hline 150 & $8.4 \mathrm{~b}$ & $0.9 \mathrm{~b}$ & 39 a & $1.4 \mathrm{a}$ & $0.3 \mathrm{~b}$ & $6.4 a b$ \\
\hline 200 & $8.3 \mathrm{~b}$ & $0.9 \mathrm{~b}$ & 38 a & $1.6 \mathrm{a}$ & $0.2 \mathrm{c}$ & $6.5 a b$ \\
\hline Significance ${ }^{x}$ & NS $\left({ }^{*}\right)$ & * & & NS $\left(^{*}\right)$ & * & $*(\mathrm{NS})$ \\
\hline \multicolumn{7}{|l|}{ Medium } \\
\hline Hconv & $13.3 \mathrm{~b}$ & $1.2 \mathrm{~b}$ & $42 \mathrm{a}$ & $6.6 \mathrm{a}$ & $0.8 \mathrm{a}$ & $5.4 \mathrm{e}$ \\
\hline $\mathrm{H} 100$ & $16.7 \mathrm{a}$ & $1.8 \mathrm{a}$ & $40 \mathrm{~b}$ & $2.3 \mathrm{~b}$ & $0.3 \mathrm{~b}$ & $7.0 \mathrm{a}$ \\
\hline $\mathrm{H} 75$ & $11.8 \mathrm{~b}$ & $1.3 \mathrm{~b}$ & $39 \mathrm{c}$ & $1.6 \mathrm{c}$ & $0.3 \mathrm{~b}$ & $6.2 \mathrm{c}$ \\
\hline $\mathrm{H} 50$ & $8.0 \mathrm{c}$ & $0.9 \mathrm{c}$ & $38 \mathrm{~cd}$ & $1.4 \mathrm{c}$ & $0.3 \mathrm{c}$ & $6.7 \mathrm{~b}$ \\
\hline $\mathrm{H} 25$ & $5.2 \mathrm{~d}$ & $0.6 \mathrm{~d}$ & $38 \mathrm{~d}$ & $1.2 \mathrm{c}$ & $0.2 \mathrm{~d}$ & $5.8 \mathrm{~d}$ \\
\hline Significance & * & * & * & * & * & * \\
\hline $\begin{array}{l}\text { Watering regime } \mathrm{x} \\
\text { medium }\end{array}$ & NS $\left(^{*}\right)$ & * & NS & NS $\left(^{*}\right)$ & NS $\left(^{*}\right)$ & *(NS) \\
\hline $\mathrm{R}^{2 \text { (organic) }}$ & 0.89 & 0.89 & 0.74 & 0.64 & 0.74 & 0.96 \\
\hline $\mathrm{R}^{2 \text { (conventional) }}$ & 0.86 & 0.86 & 0.83 & 0.96 & 0.75 & 0.97 \\
\hline \multicolumn{7}{|c|}{$\begin{array}{l}z \text { See tables } 1 \text { and } 2 \text { for composition of the media and explanations of the watering } \\
\text { regimes and treatments. }\end{array}$} \\
\hline
\end{tabular}




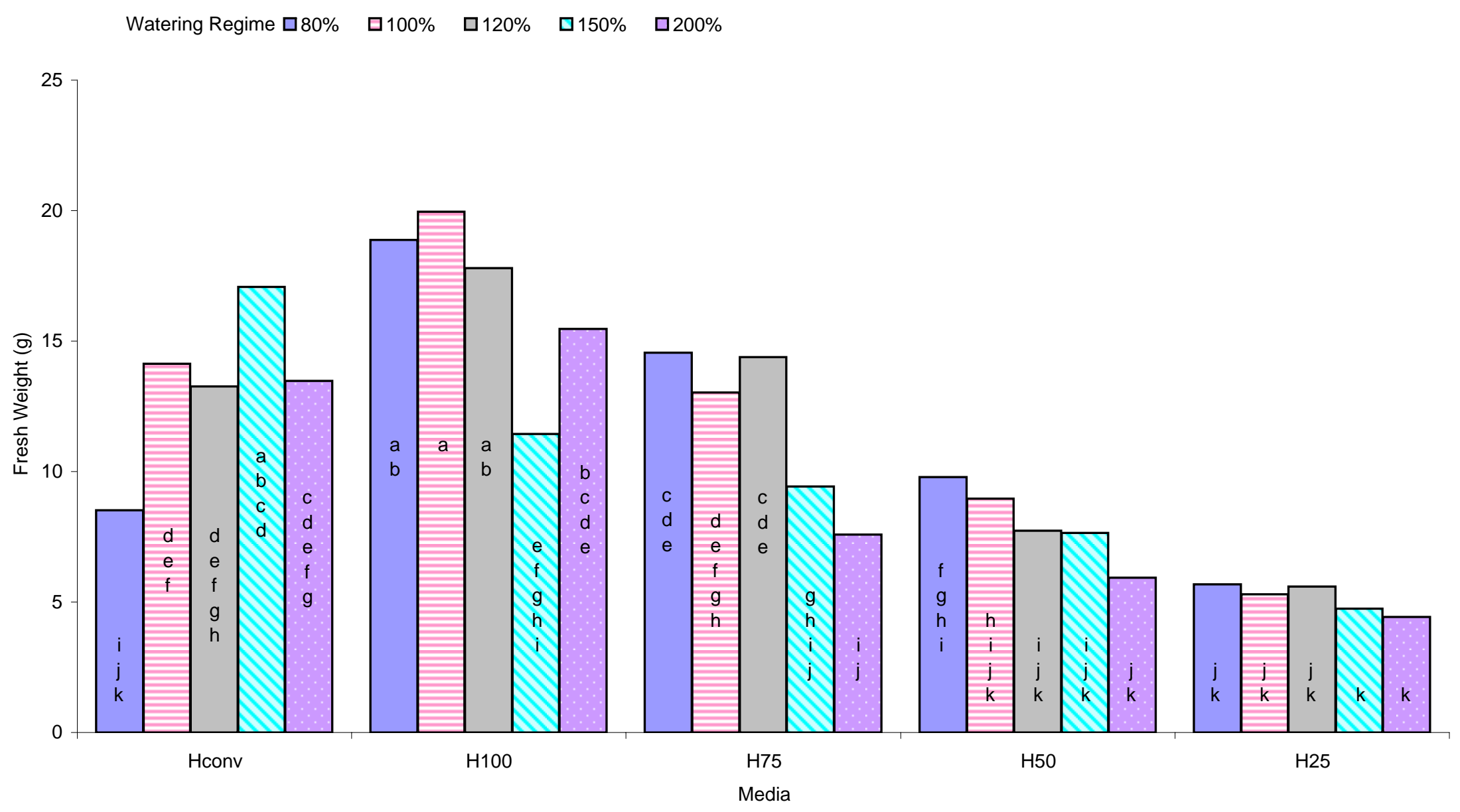

Figure 1. Shoot fresh weight in grams (g) of 4-week-old transplants in Experiment 1 grown in conventional peat-lite (Hconv) and media containing composted horse manure $(\mathrm{H} 100, \mathrm{H} 75, \mathrm{H} 50$ and $\mathrm{H} 25)$ at watering regimes of 80, 100, 120, 150 , and 200 percent container capacity $(n=3)$. Bars with the same letter do not differ significantly $(P \bullet 0.05)$ according to Duncan's Multiple Range Test. See tables 1 and 2 for composition of media and explanation of the watering regimes. 


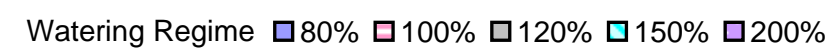

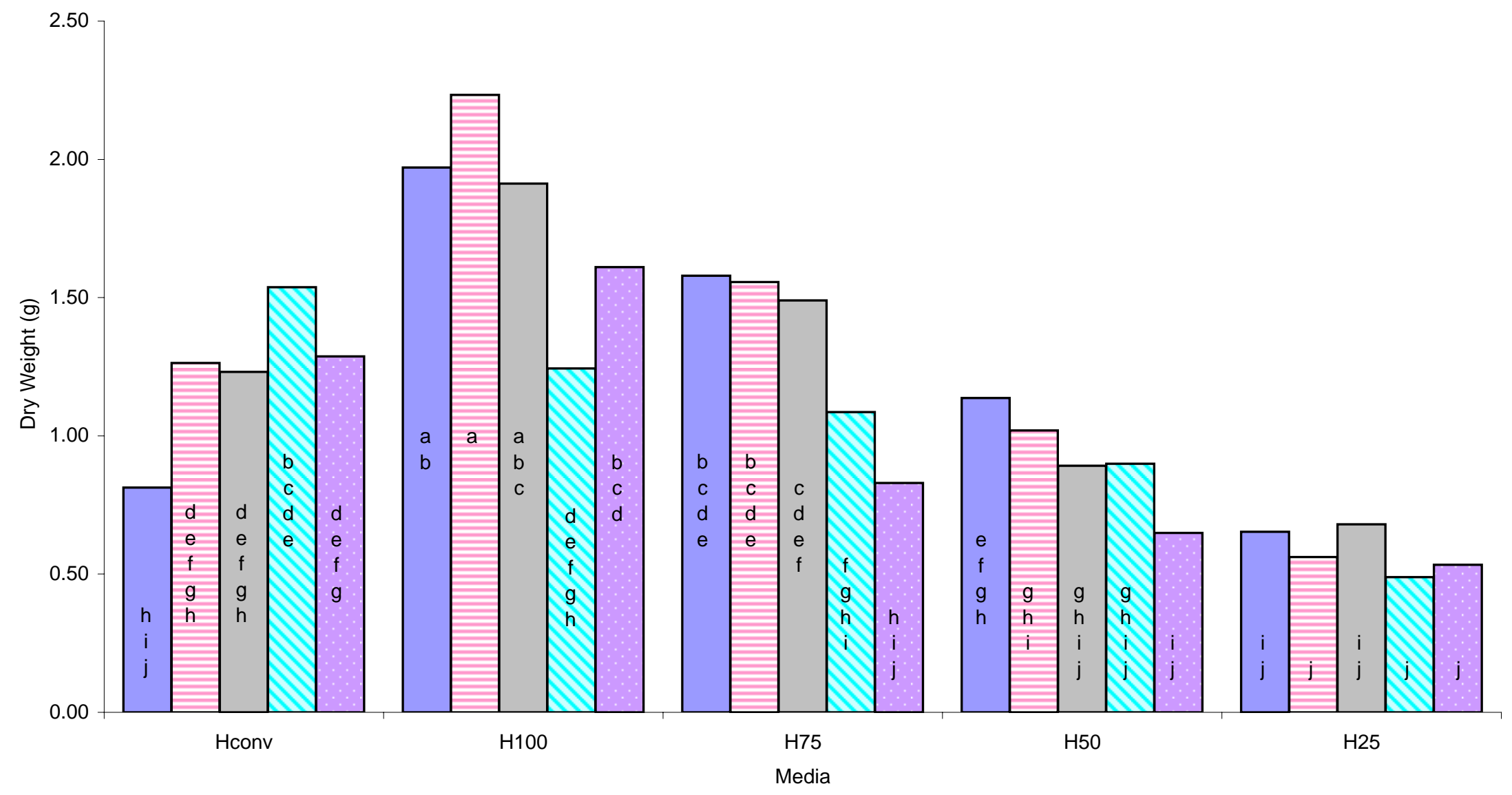

Figure 2. Shoot dry weight in grams (g) of 4-week-old transplants in Experiment 1 grown in conventional peat-lite (Hconv) and media containing composted horse manure $(\mathrm{H} 100, \mathrm{H} 75, \mathrm{H} 50$ and $\mathrm{H} 25)$ at watering regimes of $80,100,120,150$, and 200 percent container capacity $(n=3)$. Bars with the same letter do not differ significantly $(P \cdot 0.05)$ according to Duncan's Multiple Range Test. See tables 1 and 2 for composition of media and explanation of the watering regimes. 
Table 5. Percentage of dry weight based on fresh weight (dry weight \%) of the shoots of 4-week-old tomato transplants from Experiments 1 and $2(n=3) .^{z}$

\begin{tabular}{lc}
\hline \hline Medium & Dry weight $(\%)$ \\
\hline Hconv & $9 b^{\mathrm{y}}$ \\
$\mathrm{H} 100$ & $11 \mathrm{a}$ \\
$\mathrm{H} 75$ & $11 \mathrm{a}$ \\
$\mathrm{H} 50$ & $11 \mathrm{a}$ \\
$\mathrm{H} 25$ & $11 \mathrm{a}$ \\
\hline
\end{tabular}

${ }^{\mathrm{z}}$ See table 1 for media composition.

${ }^{y}$ Columns with the same letter do not differ significantly according to Duncan's multiple range test, $\mathrm{P} \leq 0.05$. 


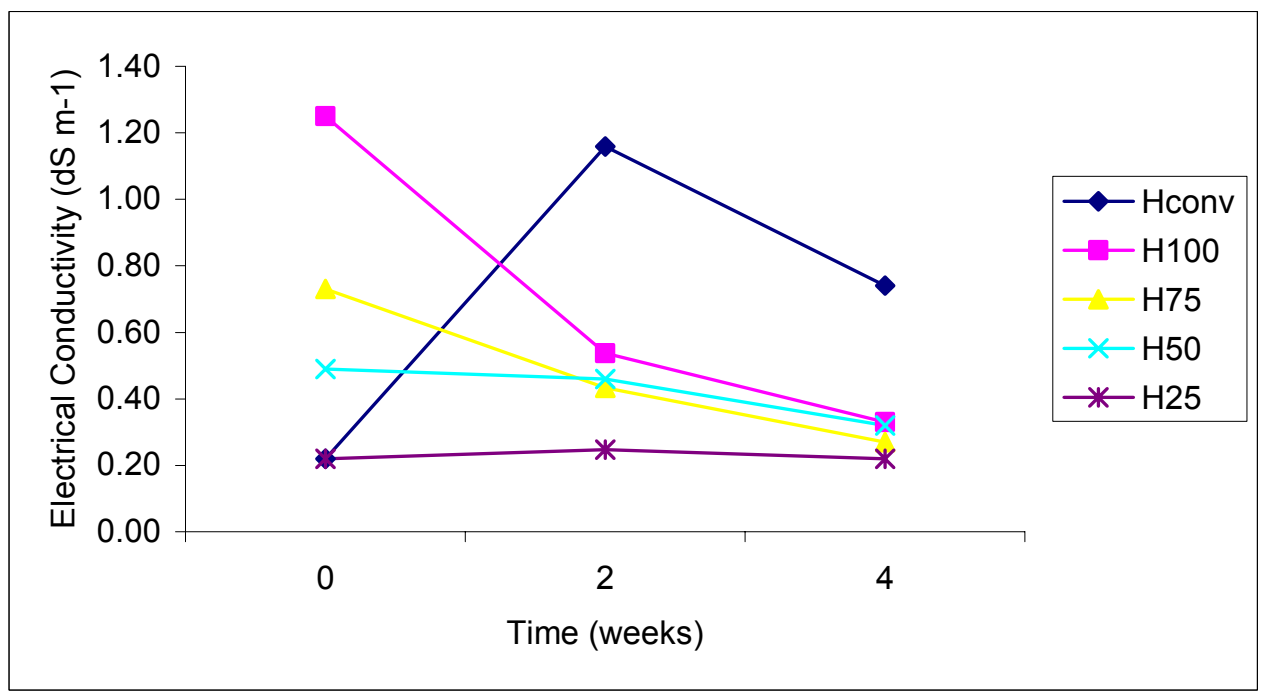

Figure 3. Change in electrical conductivity expressed in $\mathrm{dS} \mathrm{m}^{-1}$ over 4-weeks of conventional peat-lite (Hconv) and media containing composted horse manure $(\mathrm{H} 100, \mathrm{H} 75, \mathrm{H} 50$ and $\mathrm{H} 25)$ in Experiment $1(\mathrm{n}=3)$.

Change was nonsignificant (NS) or linear (L) for media Hconv, H100, H75, H50, and $\mathrm{H} 25$ at 0,2 and 4 weeks after transplanting $(\mathrm{P} \leq 0.05)$.

Hconv (L), H100 (L), H75 (L), H50 (NS), H25 (NS).

See table 1 for composition of media. 


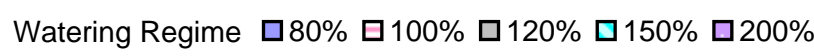

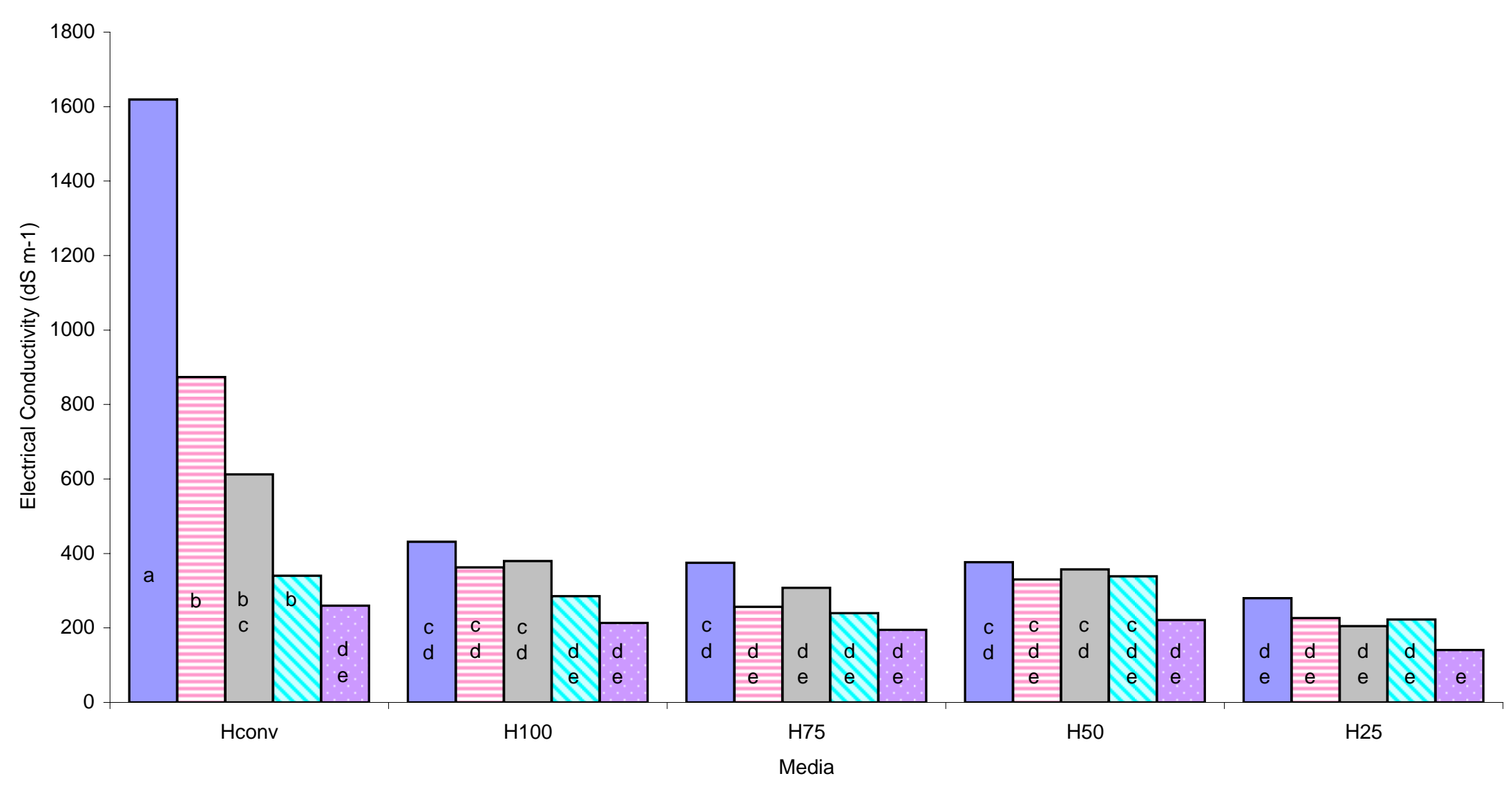

Figure 4. Electrical conductivity of media expressed in dS m-1 in Experiment 1 after 4 weeks of conventional peat-lite (Hconv) and media containing composted horse manure $(\mathrm{H} 100, \mathrm{H} 75, \mathrm{H} 50$ and $\mathrm{H} 25)$ at watering regimes of $80,100,120$, 150 , and 200 percent container capacity. $(n=3)$. Bars with the same letter do not differ significantly $(P \bullet 0.05)$ according to Duncan's Multiple Range Test. See tables 1 and 2 for composition of media and explanation of the watering regimes. 


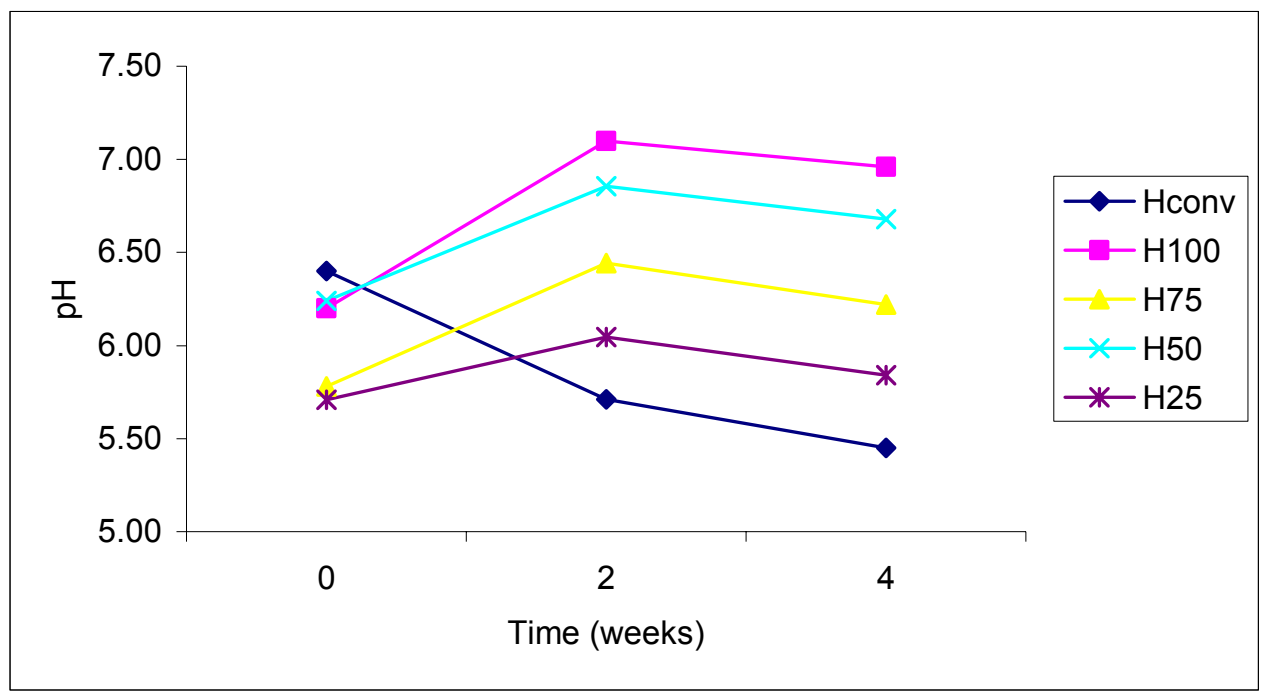

Figure 5. Change in $\mathrm{pH}$ of media over time of conventional peat-lite (Hconv) and media containing composted horse manure $(\mathrm{H} 100, \mathrm{H} 75, \mathrm{H} 50$ and $\mathrm{H} 25)$ in Experiment $1(n=3)$.

Change was quadratic for media, Hconv, $\mathrm{H} 100, \mathrm{H} 75, \mathrm{H} 50$, and $\mathrm{H} 25$ at 0,2 and 4 weeks after transplanting, $(P \leq 0.05)$.

See table 1 for composition of media. 
Table 6. Main effects (watering regime and media) and interaction of main effects (watering regime $x$ media) on dependent variables with (conventional) and without (organic) conventional treatments of Experiment $2(n=3){ }^{z}$

\begin{tabular}{|c|c|c|c|c|c|c|}
\hline & \multicolumn{6}{|c|}{ Dependent variables } \\
\hline & $\begin{array}{c}\text { Fresh } \\
\text { weight }(g)\end{array}$ & $\begin{array}{c}\text { Dry } \\
\text { Neight (g) }\end{array}$ & $\begin{array}{c}\text { Carbon } \\
\text { content } \\
(\%)\end{array}$ & $\begin{array}{c}\text { Nitrogen } \\
\text { content } \\
(\%)\end{array}$ & $\begin{array}{l}\text { Electrical } \\
\text { conductivity } \\
\text { (dS m-1) }\end{array}$ & $\mathrm{pH}$ \\
\hline \multicolumn{7}{|l|}{ Watering regime } \\
\hline 80 & $14.6 b^{y}$ & $2.0 \mathrm{ab}$ & $40 a$ & $2.5 \mathrm{a}$ & $1.0 \mathrm{a}$ & $6.0 \mathrm{~b}$ \\
\hline 100 & $16.5 \mathrm{a}$ & $2.3 \mathrm{ab}$ & $40 a b$ & $1.7 \mathrm{~b}$ & $0.8 \mathrm{~b}$ & $6.1 \mathrm{~b}$ \\
\hline 120 & $15.5 \mathrm{ab}$ & $2.2 \mathrm{ab}$ & $40 a b$ & $1.5 \mathrm{bc}$ & $0.7 \mathrm{~b}$ & $6.1 \mathrm{~b}$ \\
\hline 150 & $14.3 \mathrm{~b}$ & $1.9 \mathrm{~b}$ & $39 \mathrm{~b}$ & $1.4 \mathrm{c}$ & $0.5 \mathrm{c}$ & $6.1 \mathrm{~b}$ \\
\hline 200 & $14.5 \mathrm{~b}$ & $2.0 a b$ & $40 a b$ & $1.3 \mathrm{c}$ & $0.4 \mathrm{c}$ & $6.3 \mathrm{a}$ \\
\hline Significance $^{x}$ & * & $*(\mathrm{NS})$ & NS & * & * & $*(\mathrm{NS})$ \\
\hline \multicolumn{7}{|l|}{ Medium } \\
\hline Cconv & $23.2 \mathrm{a}$ & $2.8 \mathrm{a}$ & $40 \mathrm{a}$ & $4.7 \mathrm{a}$ & $0.3 \mathrm{c}$ & $4.8 \mathrm{~d}$ \\
\hline C100 & $13.0 \mathrm{~d}$ & $1.9 \mathrm{c}$ & $40 \mathrm{a}$ & $1.3 \mathrm{c}$ & $0.8 \mathrm{a}$ & $7.0 \mathrm{a}$ \\
\hline C75 & $15.9 \mathrm{bc}$ & $2.3 \mathrm{~b}$ & $41 \mathrm{a}$ & $2.1 \mathrm{~b}$ & $0.8 \mathrm{a}$ & $6.5 \mathrm{~b}$ \\
\hline C50 & $16.6 \mathrm{~b}$ & $2.2 \mathrm{~b}$ & $40 \mathrm{a}$ & $1.9 \mathrm{~b}$ & $0.6 \mathrm{~b}$ & $6.0 \mathrm{c}$ \\
\hline C25 & $14.8 \mathrm{c}$ & $1.9 \mathrm{c}$ & $38 \mathrm{~b}$ & $1.3 \mathrm{c}$ & $0.5 \mathrm{~b}$ & $5.0 \mathrm{~d}$ \\
\hline Significance & * & * & * & * & * & * \\
\hline $\begin{array}{l}\text { Watering regime } \mathrm{x} \\
\text { medium }\end{array}$ & * & * & NS & * & * & NS \\
\hline $\mathrm{R}^{2 \text { (organic) }}$ & 0.76 & 0.64 & 0.59 & 0.82 & 0.82 & 0.96 \\
\hline $\mathrm{R}^{2 \text { (conventional) }}$ & 0.91 & 0.78 & 0.58 & 0.96 & 0.83 & 0.93 \\
\hline
\end{tabular}

$\mathrm{z}$ See tables 1 and 2 for composition of the media and explanations of the watering regimes and treatments.

${ }^{y}$ Columns with the same letter do not differ significantly according to Duncan's multiple range test, $P \leq 0.05$.

$x$ Significance in parenthesis (NS, ${ }^{*}$ ) ANOVA analysis includes conventional treatments. NS, * Nonsignificant (NS) or significant $\left({ }^{*}\right)$ at $\mathrm{P} \leq 0.05$ level determined by ANOVA. 


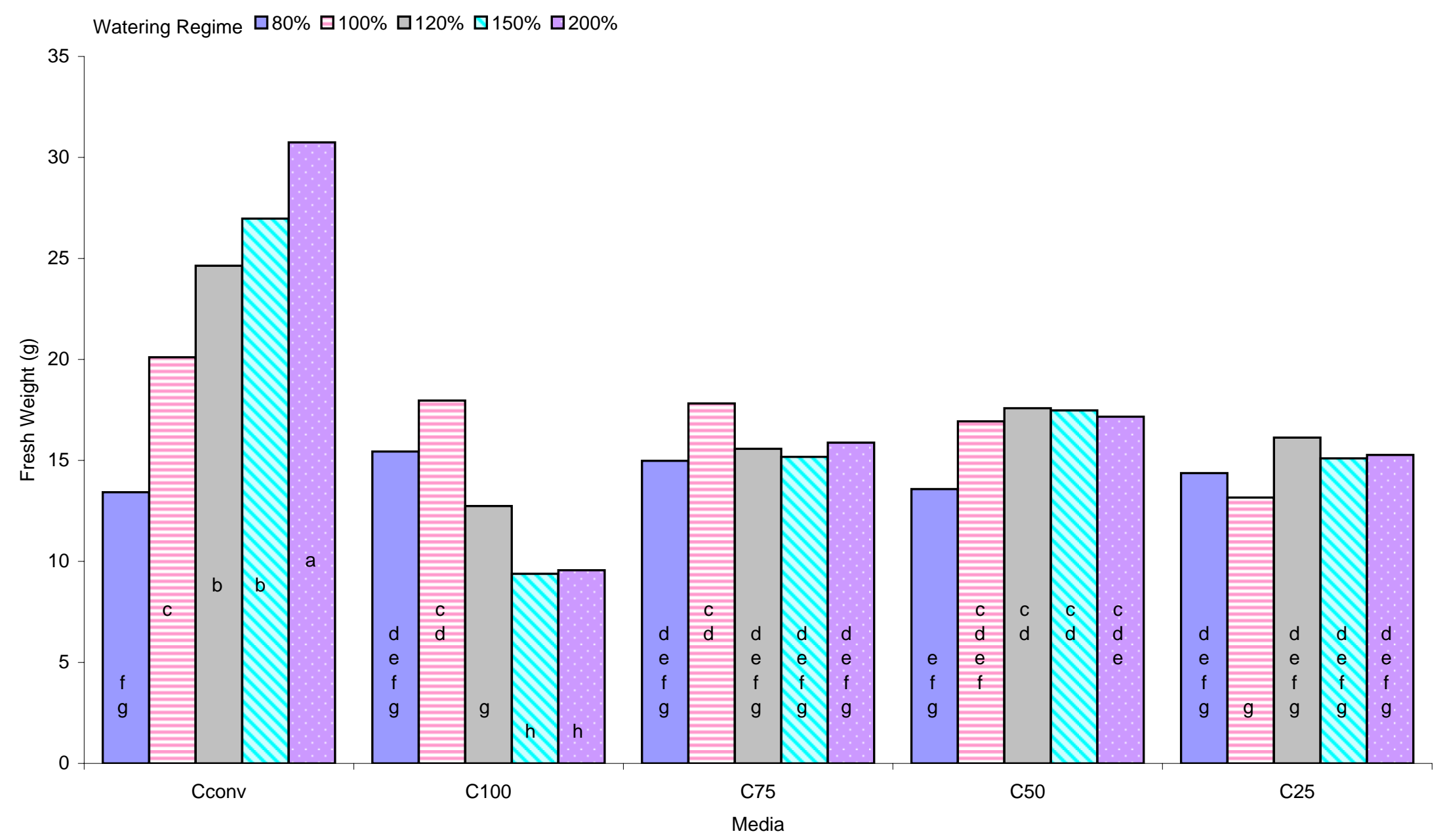

Figure 6. Shoot fresh weight in grams (g) of 4-week-old transplants in Experiment 2 grown in conventional peat-lite (Cconv) and media containing composted cow manure (C100, C75, C50 and C25) at watering regimes of 80, 100, 120, 150 , and 200 percent container capacity $(n=3)$. Bars with the same letter do not differ significantly $(P \cdot 0.05)$ according to Duncan's Multiple Range Test. See tables 1 and 2 for composition of media and explanation of the watering regimes. 


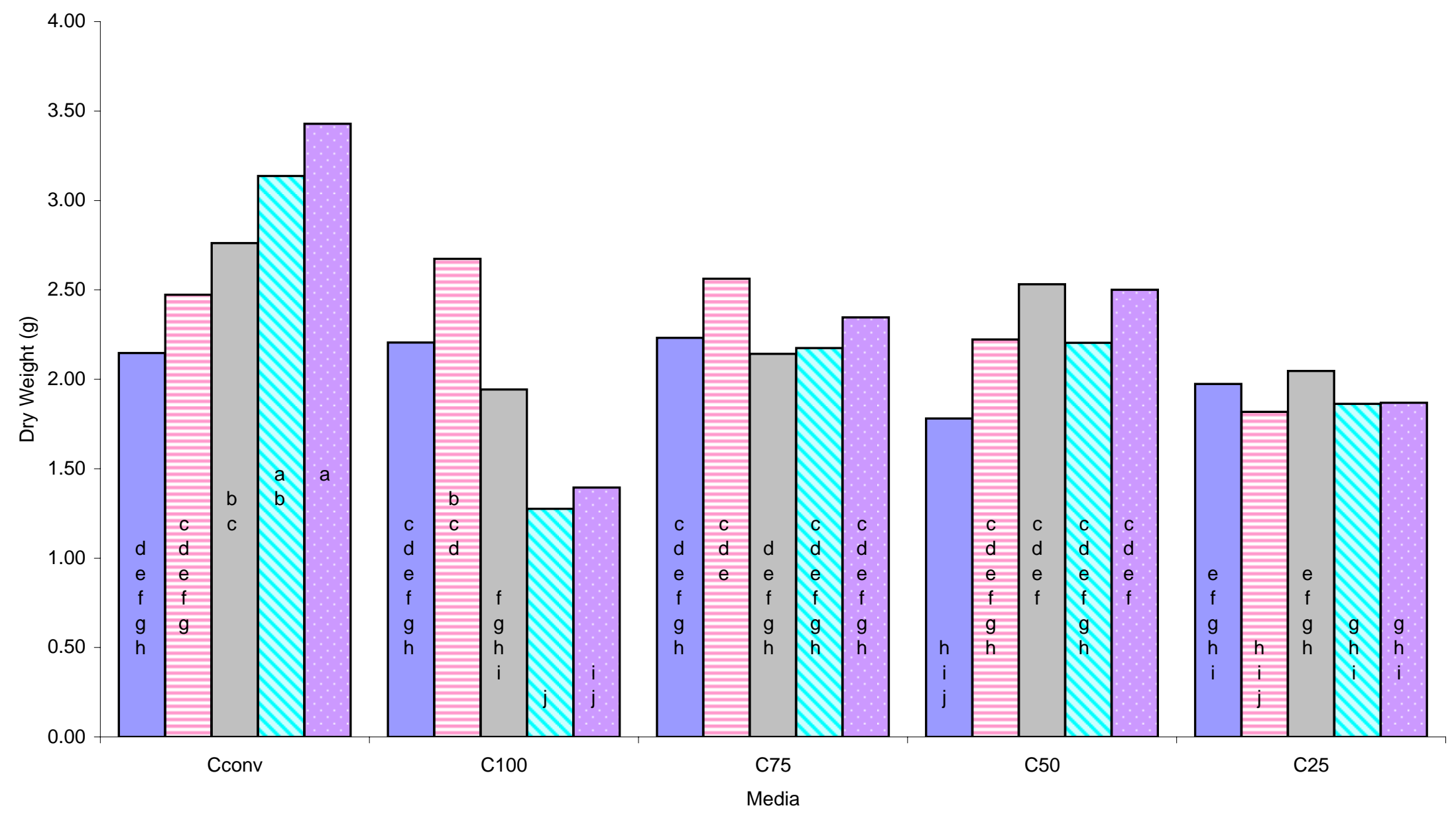

Figure 7. Shoot dry weight in grams (g) of 4-week-old transplants in Experiment 2 grown in conventional peat-lite (Cconv) and media containing composted cow manure (C100, C75, C50 and C25) at watering regimes of 80, 100,120,150, and 200 percent container capacity $(n=3)$. Bars with the same letter do not differ significantly $(P \cdot 0.05)$ according to Duncan's Multiple Range Test. See tables 1 and 2 for composition of media and explanation of the watering regimes. 
Table 7. Percentage of dry weight based on fresh weight (dry weight \%) of the shoots of 4-week-old tomato transplants from Experiments 1 and $2(n=3) .^{z}$

\begin{tabular}{lc}
\hline \hline Medium & Dry weight (\%) \\
\hline Cconv & $12 \mathrm{c}^{\mathrm{y}}$ \\
C100 & $15 \mathrm{a}$ \\
C75 & $14 \mathrm{a}$ \\
C50 & $14 \mathrm{ab}$ \\
C25 & $13 \mathrm{bc}$ \\
\hline
\end{tabular}

${ }^{\mathrm{z}}$ See table 1 for media composition.

${ }^{y}$ Columns with the same letter do not differ significantly according to Duncan's multiple range test, $P \leq 0.05$. 


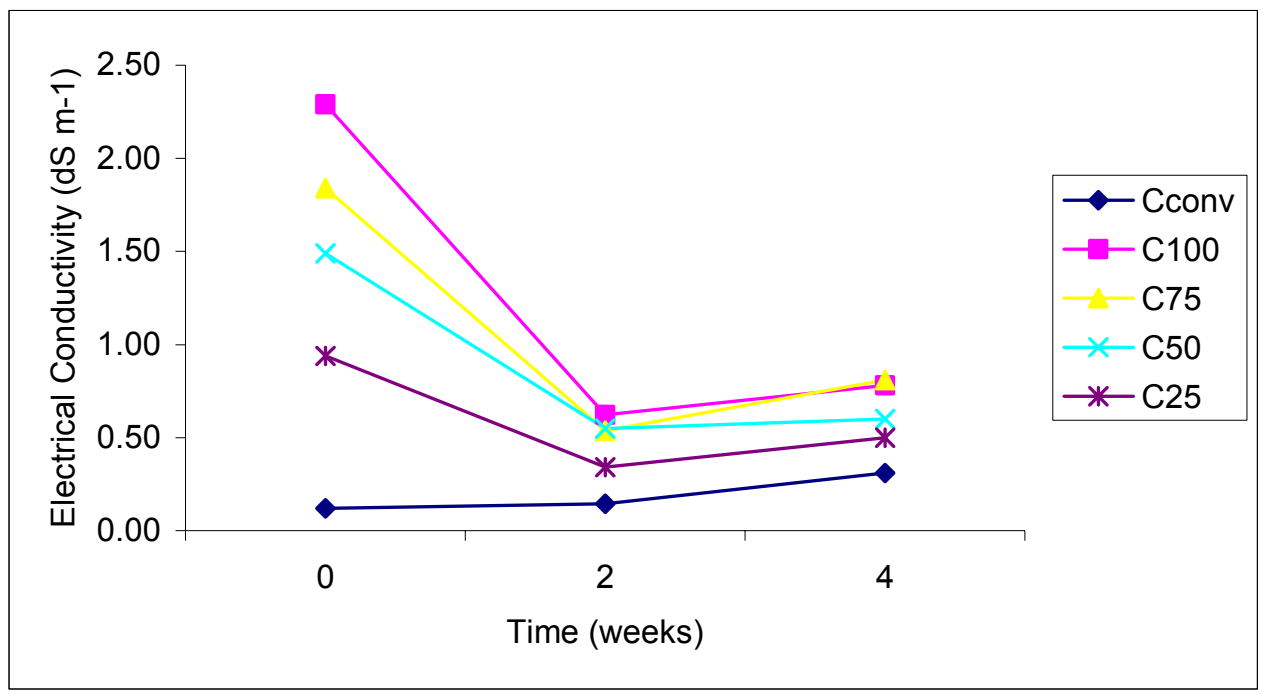

Figure 8. Change in electrical conductivity expressed in $\mathrm{dS} \mathrm{m}^{-1}$ over time of conventional peat-lite (Cconv) and media containing composted cow manure (C100, C75, C50 and C25) in Experiment $2(n=3)$.

Change was nonsignificant (NS) or quadratic (Q) for media Cconv, C100, C75, $\mathrm{C} 50$, and $\mathrm{C} 25$ at 0,2 and 4 weeks after transplanting, $(P \leq 0.05)$.

Cconv (Q), C100 (Q), C75 (NS), C50 (Q), C25 (Q).

See table 1 for composition of media. 


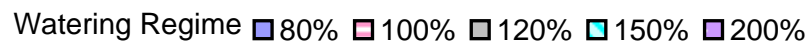

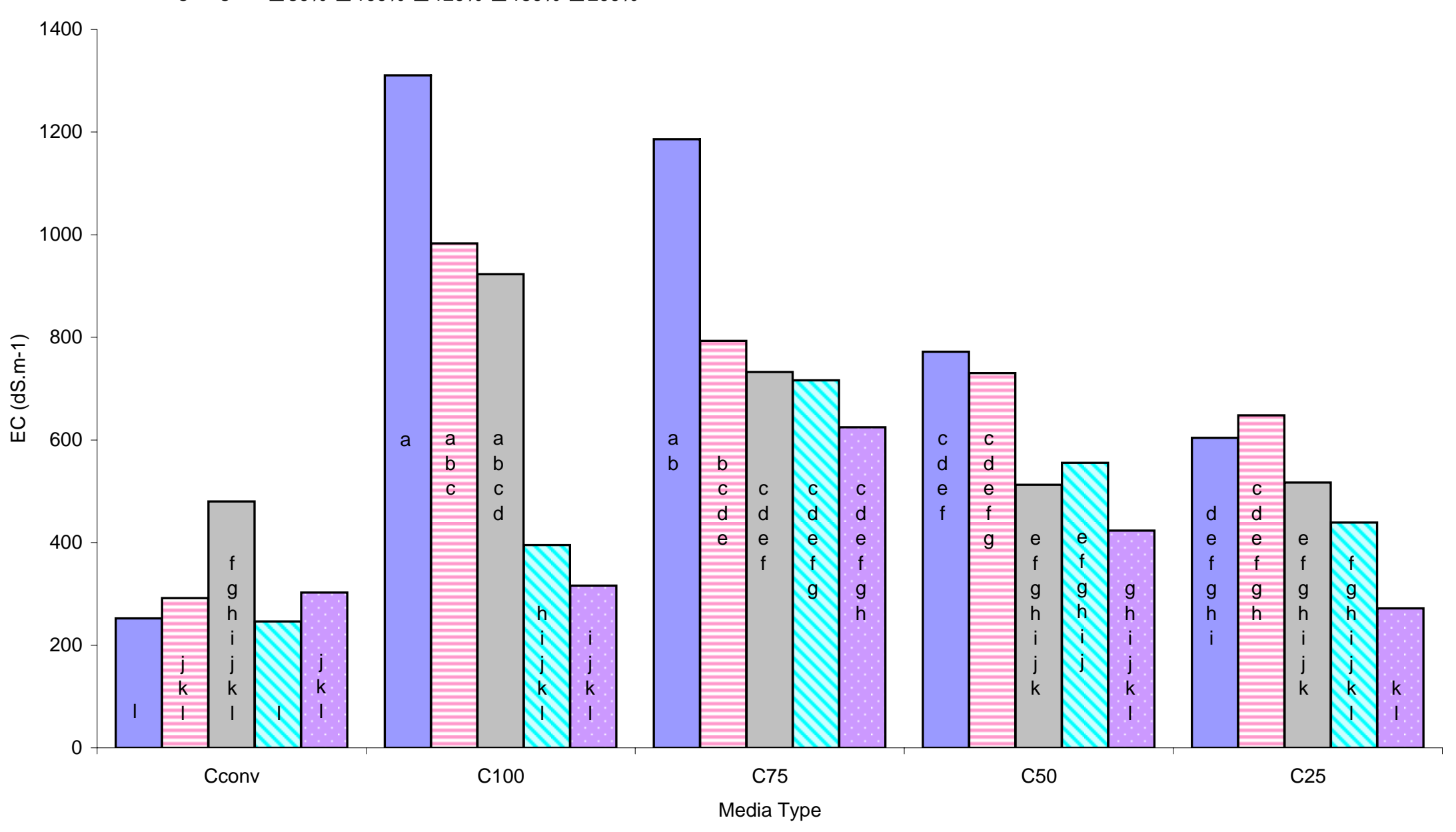

Figure 9. Electrical conductivity of media expressed in dS m-1 in Experiment 2 after 4 weeks of conventional peat-lite (Cconv) and media containing composted cow manure (C100, C75, C50 and C25) at watering regimes of 80, 100, 120, 150, and 200 percent container capacity. $(n=3)$. Bars with the same letter do not differ significantly $(P \bullet 0.05)$ according to Duncan's Multiple Range Test. See tables 1 and 2 for composition of media and explanation of the watering regimes. 


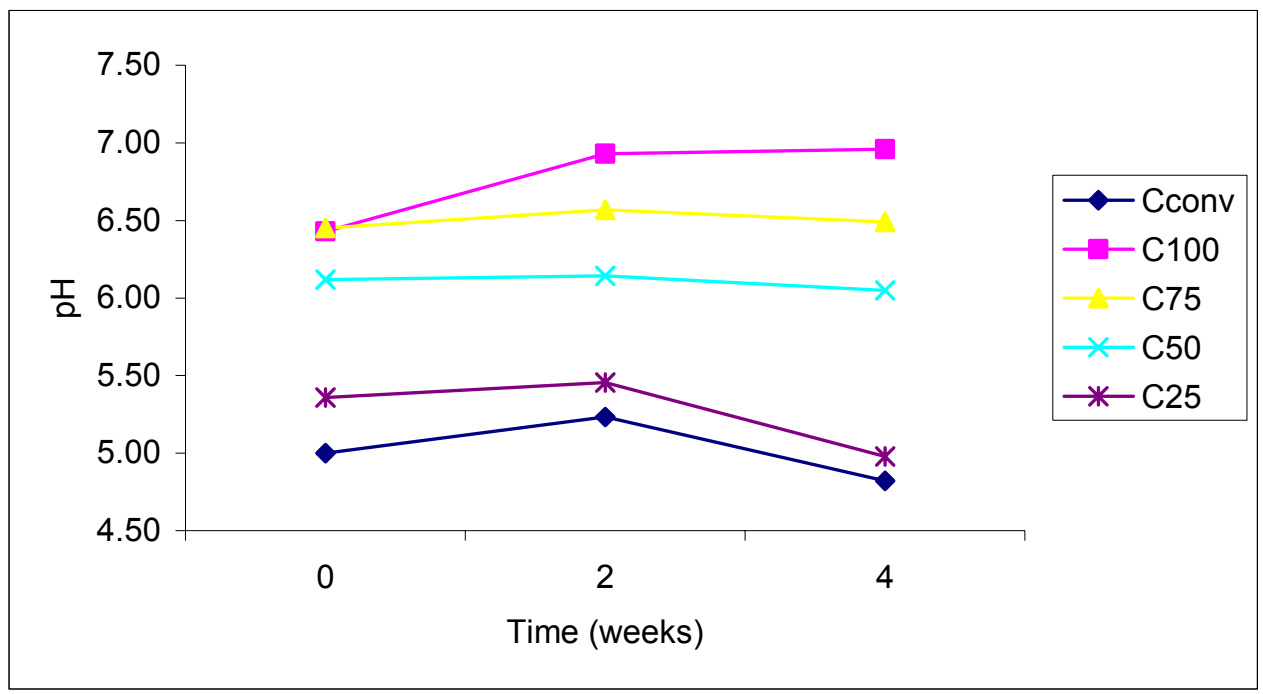

Figure 10. Change in $\mathrm{pH}$ over time of conventional peat-lite (Cconv) and media containing composted cow manure (C100, C75, C50 and C25) in Experiment 2 $(n=3)$.

Change was nonsignificant (NS) or linear (L) for media Cconv, C100, C75, C50, and $\mathrm{C} 25$ at 0,2 and 4 weeks after transplanting, $(P \leq 0.05)$.

Cconv (L), C100 (L), C75 (L), C50 (NS), C25 (NS).

See table 1 for composition of media. 
Table 8. Main effects (watering regime, media and compost tea) and interaction of main effects (watering regime $x$ media $x$ compost tea) on dependent variables of Experiment $1(n=3){ }^{z}$

Dependent variables

Fresh weight Dry weight Electrical conductivity

(g)

(g)

(dS m-1)

Watering regime

120

150

$11.6 \mathrm{a}^{\mathrm{y}}$

$1.3 \mathrm{a}$

$0.3 \mathrm{a}$

200

Significance

$9.4 \mathrm{~b}$

$1.0 \mathrm{~b}$

$0.3 \mathrm{~b}$

$8.4 \mathrm{~b}$

$0.9 \mathrm{c}$

$0.2 \mathrm{c}$

Medium

$\mathrm{H} 100$

$\mathrm{H} 75$

$14.3 \mathrm{a}$

$1.6 \mathrm{a}$

$0.3 \mathrm{a}$

$11.7 \mathrm{~b}$

$1.3 \mathrm{~b}$

$0.3 \mathrm{a}$

$\mathrm{H} 50$

$7.5 \mathrm{c}$

$0.8 \mathrm{c}$

$0.2 \mathrm{~b}$

$\mathrm{H} 25$

Significance

$5.8 \mathrm{~d}$

$0.7 \mathrm{~d}$

$0.2 \mathrm{c}$

Watering regime $x$ medium

Compost tea

*

*

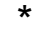

* * NS

*

*

NS

Watering regime $x$ compost

tea

Medium $x$ compost tea

NS

NS NS

* * NS

Watering regime $x$ compost

tea $\mathrm{x}$ medium

NS

NS

NS

$\mathrm{R}^{2}$

0.88

0.88

0.78

${ }^{\mathrm{z}}$ See tables 1 and 2 for composition of the media and explanations of the watering regime.

${ }^{y}$ Columns with the same letter do not differ significantly according to Duncan's multiple range test, $\mathrm{P} \leq 0.05$.

NS, * Nonsignificant (NS) or significant (*) at $\mathrm{P} \leq 0.05$ level determined by ANOVA. 
Table 9. Main effects (watering regime, media and compost tea) and interaction of main effects (watering regime $x$ media $x$ compost tea) on dependent variables of Experiment $2(n=3){ }^{z}$

$\frac{\text { Dependent variables }}{\text { Electrical }}$

Watering regime

120

150

200

Significance

(g)

(g) $\mathrm{m}-1)$

Medium

C100

C75

$15.8 a^{y}$

$2.2 \mathrm{a}$

$0.7 \mathrm{a}$

$15.4 \mathrm{a}$

$2.2 \mathrm{a}$

$0.6 \mathrm{a}$

$15.1 \mathrm{a}$

$2.0 \mathrm{a}$

NS

NS

$0.4 \mathrm{~b}$

*

C50

C25

Significance

Watering regime $x$ medium

Compost tea

Watering regime $x$ compost tea

Medium $x$ compost tea

$11.3 \mathrm{c}$

$16.5 \mathrm{ab}$

$1.6 \mathrm{c}$

$0.6 \mathrm{a}$

$18.0 \mathrm{a}$

$2.4 \mathrm{a}$

$0.7 \mathrm{a}$

$15.9 \mathrm{~b}$

$2.4 \mathrm{a}$

$0.6 \mathrm{ab}$

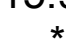

$2.0 \mathrm{~b}$

$0.5 \mathrm{~b}$

*

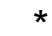

*

NS NS NS

* NS *

NS NS NS

NS NS NS

Watering regime $x$ compost tea $x$ medium

NS NS NS

$\mathrm{R}^{2}$

0.64

0.54

0.65

${ }^{\mathrm{z}}$ See tables 1 and 2 for composition of the media and explanations of the watering regime.

${ }^{y}$ Columns with the same letter do not differ significantly according to Duncan's multiple range test, $\mathrm{P} \leq 0.05$.

NS, * Nonsignificant (NS) or significant $\left({ }^{*}\right)$ at $\mathrm{P} \leq 0.05$ level determined by ANOVA. 


\section{LITERATURE CITED}

Argo, W.R. 1998. Root medium chemical properties. HortTechnology 8(4):486494.

Biernbaum, J.A, and N.B. Versluys. 1998. Water Management. HortTechnology 8(4): 504-509.

Boodley, J.W., and Sheldrake, R. 1982. Cornell peat-lite mixes for commercial plant growing. Cornell Extension Info. Bul. 43.

Bugbee, G.J. 1994. Growth of rudbeckia and leaching of nitrates in potting media amended with composted coffee processing residue, municipal solid waste and sewage sludge. Compost Sci. Util. 2(1):72-79.

Corti, C., L. Crippa, P.L. Genevini, and M. Centemero. 1998. Compost use in plant nureries: hydrological and physicochemical characteristics. Compost Sci. Util. 6(1):35-45.

D’Angelo, G., M. Pusterla, and M. Castelnuovo. 1995. Response of peat- and compost-based substrates to different levels of irrigation and fertilization in cyclamen. Acta Hort. 401:537-543.

Duram, L.A. 1999. Factors in organic farmers' decisionmaking: diversity, challenge, and obstacles. Amer. J. Alternative Agric. 14:2-10.

Eklind, Y., B. Ramert, and M. Wivstad. 2001. Evaluation of growing media containing farmyard manure compost, household waste compost or chicken manure for the propagation of lettuce (Lactuca sativa L.) transplants. Biol. Agric. Hort. 19:157-181.

Epstein, E. 1997. The science of composting. Technomic Publishers Lancaster, $\mathrm{Pa}$.

Fonteno, W.C., D.K. Cassel, and R.A. Larson. 1981. Physical properties of three container media and their effect on poinsettia growth. J. Amer. Soc. Hort. Sci. 106(6):736-741. 
Freeman, T.M., and D.L. Cawthon.1999. Use of composted dairy cattle solid biomass, poultry litter and municipal biosolids as greenhouse growth media. Compost Sci. Util. 7(3):66-71.

Gagnon B., and S. Berrouard. 1993. Effects of several organic fertilizers on growth of greenhouse tomato transplants. Can. J. Plant Sci. 74(1):167-168.

Gouin, F.R. 1995. Market strength in horticultural industries. BioCycle 36(8):6870.

Greene, C., and A. Kremen. 2003. U.S. organic farming in 2000-2001: adoption of certified systems. USDA, ERS, Resource Economics Division, Agric. Info. Bul. No. 780. Washington, D.C.

Greene, C. 2001. U.S. organic farming emerges in the 1990s: adoption of certified systems. USDA, ERS, Resource Economics Division, Agric. Info. Bul. No. 770. Washington, D.C.

Greene, C., C. Dimitri, and N. Richman. 2001. Organic marketing features fresh foods and direct exchange. FoodReview 24(1):31-37.

Groves, K.M., S.L. Warren, and T.E. Bilderback. 1998. Irrigation volume, application, and controlled-release fertilizers: II. Effect on substrate solution nutrient concentration and water efficiency in containerized plant production. $\mathrm{J}$. Environ. Hort. 16(3):182-188.

Havlin, J., J. Beaton, S. Tisdale, and W. Nelson. 1999. Soil fertility and fertilizers: an introduction to nutrient management. $6^{\text {th }}$ ed. Prentice Hall, Upper Saddle River, New Jersey.

Hoitink, H.A.J., and M.J. Boehm. 1999. Biocontrol within the context of soil microbial communities: a substrate-dependent phenomenon. Annu. Rev. Phytopathol. 37:427-46.

Hoitink, H., Y. Inbar, and M. Boehm. 1991. Status of compost-amended potting mixes naturally suppressive to soilborne diseases of floricultural crops. Plant Dis. 75(9):869-873. 
Ingham, E.R. 2002. The compost tea brewing manual, $3^{\text {rd }}$ ed. Soil Foodweb Inc. Corvallis, OR.

Kraus, H.T., R.L. Mikkelsen, and S.L. Warren. 2000. Container substrate temperatures affect mineralization of composts. HortScience 35(1):16-18.

Kreij, C. de. 1995. Latest insights into water and nutrient control in soilless cultivation. Acta Hortic. 408:47-61.

Kuepper, G., and K. Adam. 2002. Organic potting mixes for certified production. As posted 10, July, 2004. <http://attra.ncat.org/attra-pub/PDF/potmix.pdf>.

Liptay, A., and S. Nicholls. 1993. Nitrogen supply during greenhouse transplant production affects subsequent tomato root growth in the field. J. Amer. Soc. Hort. Sci. 118(3):339-342.

Markovic, V., M. Djurovka, and Z. Ilin. 1997. The effect of seedling quality on tomato yield, plant and fruit characteristics. Acta Hortic. 462:163-169.

Nelson, P.V. 1991. Greenhouse operation and management. $4^{\text {th }}$ ed. Prentice Hall, Englewood Cliffs, New Jersey.

Ozores-Hampton, M., C.S. Vavrina, and T.A. Obreza. 1999. Yard trimmingbiosolids compost: possible alternative to sphagnum peat moss in tomato transplant production. Compost Sci. Util. 7(4):42-49.

Paul, J.L., and C.I. Lee. 1976. Relation between various growth of chrysanthemums and aeration of various container media. J. Amer. Soc. Hort. Sci. 101(5):500-503.

Pryce, S. 1991. Alternatives to peat. Prof. Hortic. 5(3):101-106.

Raviv, M., B.Z. Zaidman, and Y. Kapulnik. 1998. The use of compost as a peat substitute for organic vegetable transplants production. Compost Sci. Util. $6(1): 46-52$.

Raviv, M., and Shlomit, M. 1997. Physical characteristics of separated cattle manure compost. Compost Sci. Util. 5(3):44-47. 
Raviv, M, Y. Chen, and Y. Inbar 1986. Peat and peat substitutes as growth media for container-grown plants. In: Chen, Y. and Y. Avnimelech (eds.). The role of organic matter in modern agriculture. Dordrecht ; Boston Martinus Nijhoff.

Rhoades, J.D. 1982. Cation exchange capacity. In: Page, A., R. Miller, and D. Keeney (eds.). Methods of Soil Analysis, Part 2. Chemical and microbiological properties - agronomy monograph no. $9\left(2^{\text {nd }}\right.$ ed $)$. Amer. Soc. Of Agronomy and Soil Sci. Soc. of Amer. ; Madison, WI.

Robertson, R.A. 1993. Peat, horticulture and environment. Biodivers. Conserv. 2(5):541-547.

Salisbury, F.B., and C.W. Ross. 1985. Plant Physiology. Belmont, CA, Wadsworth Publ.

Sellen, D., J.H. Tolman, G.R. McLoed, A. Weersink, and E.K.Yiridoe. 1995. A comparison of financial returns during early transition from conventional to organic vegetable production. J. Veg. Prod. 1:11-39.

Taiganides, E. 1977. Animal Wastes. London, Applied Science Publishers.

Tilt, K.M., T.E. Bilderback, and W.C. Fonteno. 1987. Particle size and container size effects on growth of three ornamental species. J. Amer. Soc. Hort. Sci. 112(6):981-984.

Tyler, H.H., S.L. Warren, and T.E. Bilderback. 1996. Reduced leaching fractions improve irrigation use efficiency and nutrient efficacy. J. Environ. Hort. 14(4):199204.

USDA/AMS. 2002. The national organic program. As posted June 30, 2004. $<$ http://www.ams.usda.gov/nop/indexlE.htm>.

Vandeman, A.M., and B. Hayden. 1997. New law paves way for expanding organic market. FoodReview v. 20 (2):28-32. 
Vavrina, C.S., G.J. Hochmuth, J.A. Cornell, and S.M. Olson. 1998. Nitrogen fertilization of florida-grown tomato transplants: seasonal variation in greenhouse and field performance. HortScience 33(2):251-254.

Weaver, R.D., D.J. Evans, and A.E. Luloff. 1992. Pesticide use in tomato production: consumer concerns and willingness-to-pay. Agribusiness. 8(2):131142.

Weston, L.A., and B.H. Zandstra. 1989. Transplant age and $\mathrm{N}$ and $\mathrm{P}$ nutrition effects on growth and yield of tomatoes. HortScience 24(1):88-90.

Weston, L.A., and B.H. Zandstra. 1986. Effect of root container size and location of production on growth and yield of tomato transplants. J. Amer. Soc. Hort. Sci. 111(4):498-501. 